\title{
Isolation, Screening, and Identification of Cellulolytic Bacteria from Natural Reserves in the Subtropical Region of China and Optimization of Cellulase Production by Paenibacillus terrae ME27-1
}

\author{
Yan-Ling Liang, Zheng Zhang, Min Wu, Yuan Wu, and Jia-Xun Feng \\ State Key Laboratory for Conservation and Utilization of Subtropical Agro-Bioresources, \\ Key Laboratory of Ministry of Education for Microbial and Plant Genetic Engineering, College of Life Science and Technology, \\ Guangxi University, 100 Daxue Road, Nanning, Guangxi 530004, China
}

Correspondence should be addressed to Jia-Xun Feng; jiaxunfeng@sohu.com

Received 11 February 2014; Accepted 8 May 2014; Published 19 June 2014

Academic Editor: Encarnación Ruiz

Copyright () 2014 Yan-Ling Liang et al. This is an open access article distributed under the Creative Commons Attribution License, which permits unrestricted use, distribution, and reproduction in any medium, provided the original work is properly cited.

\begin{abstract}
From different natural reserves in the subtropical region of China, a total of 245 aerobic bacterial strains were isolated on agar plates containing sugarcane bagasse pulp as the sole carbon source. Of the 245 strains, 22 showed hydrolyzing zones on agar plates containing carboxymethyl cellulose after Congo-red staining. Molecular identification showed that the 22 strains belonged to 10 different genera, with the Burkholderia genus exhibiting the highest strain diversity and accounting for $36.36 \%$ of all the 22 strains. Three isolates among the 22 strains showed higher carboxymethyl cellulase (CMCase) activity, and isolate ME27-1 exhibited the highest CMCase activity in liquid culture. The strain ME27-1 was identified as Paenibacillus terrae on the basis of 16S rRNA gene sequence analysis as well as physiological and biochemical properties. The optimum $\mathrm{pH}$ and temperature for CMCase activity produced by the strain ME27-1 were 5.5 and $50^{\circ} \mathrm{C}$, respectively, and the enzyme was stable at a wide $\mathrm{pH}$ range of 5.0-9.5. A 12-fold improvement in the CMCase activity $(2.08 \mathrm{U} / \mathrm{mL})$ of ME27-1 was obtained under optimal conditions for CMCase production. Thus, this study provided further information about the diversity of cellulose-degrading bacteria in the subtropical region of China and found P. terrae ME27-1 to be highly cellulolytic.
\end{abstract}

\section{Introduction}

With decades of studies on cellulose bioconversion, cellulases have been playing an important role in producing fermentable sugars from lignocellulosic biomass. Usually, cellulases are mainly composed of three types of synergistic enzymes: endoglucanases (EC 3.2.1.4) that hydrolyze the exposed cellulose chains of the cellulose polymer, exoglucanases (cellobiohydrolases, EC 3.2.1.91) that act to release cellobiose from the reducing and nonreducing ends, and $\beta$ glucosidases (EC 3.2.1.21) that help to cleave the cellobiose and short-chain cello-oligosaccharide into glucose [1].

Numerous microorganisms that are able to degrade cellulose have been isolated and identified. However, many studies have put more emphasis on fungi because the cellulases that they produce are abundant and easy to extract, and some of the fungal cellulases have been used as commercial cellulase [2]. Although fungi such as Trichoderma, Aspergillus, Penicillium, Phanerochaete, and Fomitopsis have been widely studied in recent years, researchers have also been paying attention to various bacteria that produce cellulases because of their fast growth, expression of multienzyme complexes, and resistance to extreme environments [3-8]. Bacteria belonging to the genera Clostridium, Cellulomonas, Cellulosimicrobium, Thermomonospora, Bacillus, Ruminococcus, Erwinia, Bacteriodes, Acetovibrio, Streptomyces, Microbispora, Fibrobacter, and Paenibacillus have been observed to produce different kinds of cellulase when incubated under anaerobic or aerobic conditions $[4,9,10]$.

Several studies have been carried out to investigate the carboxymethyl cellulase (CMCase) activity of aerobic bacteria. For instance, a maximum CMCase activity $(0.48 \mathrm{U} / \mathrm{mL})$ 


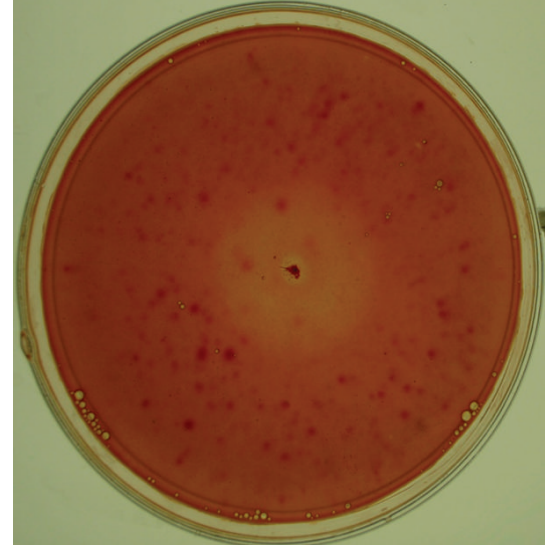

(a)

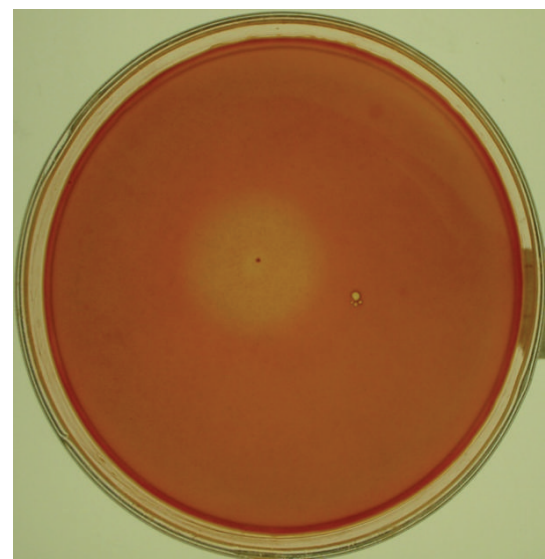

(d)

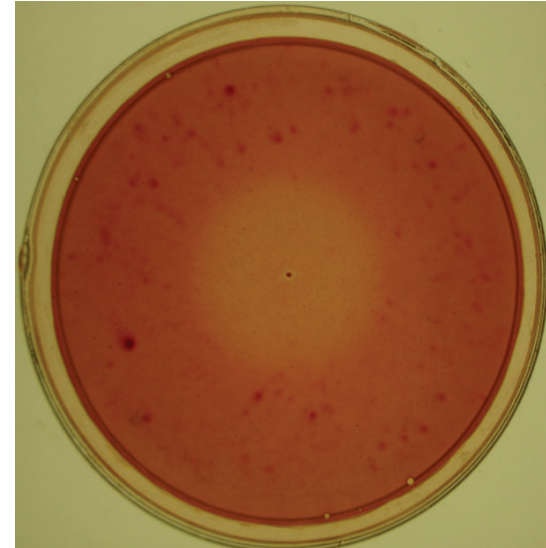

(b)

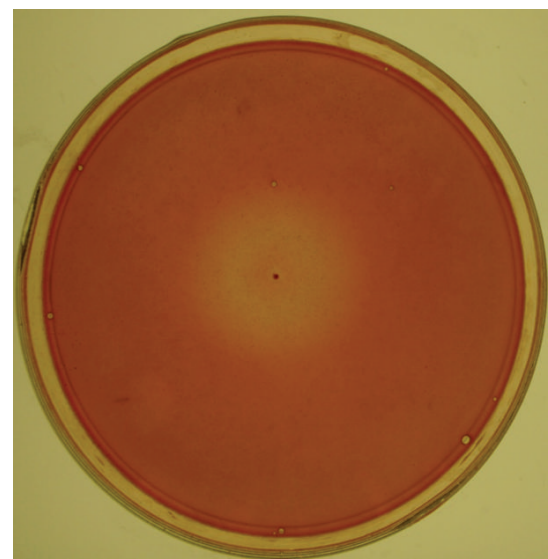

(e)

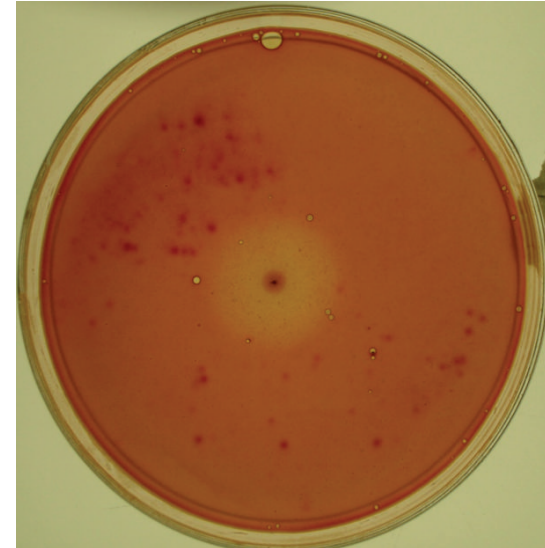

(c)

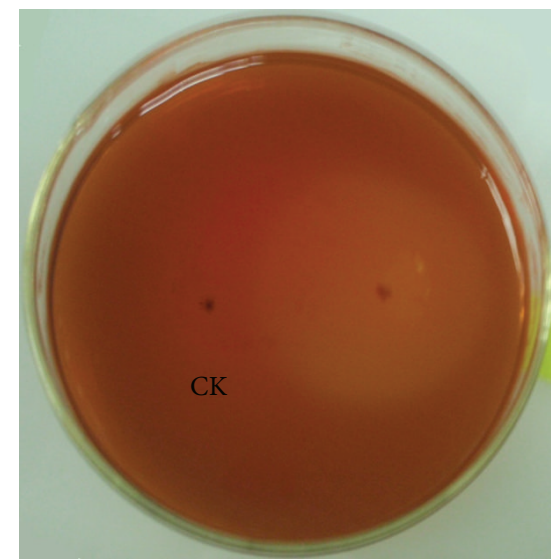

(f)

FIGURE 1: Hydrolyzing zones produced by bacterial strains on agar plates containing CMC after Congo-red staining. (a) Strain BS16-3, (b) strain FCD1-3, (c) strain FCD2-1, (d) strain FCD3-5, (e) strain FCD7-2, (f) strain SK3-4, and (CK) Escherichia coli DH5 $\alpha$.

of Acinetobacter anitratus was observed in the late logarithm phase [11]. Rastogi et al. reported that a maximum CMCase activity of 0.02 and $0.058 \mathrm{U} / \mathrm{mL}$ was exhibited by Brevibacillus sp. DUSELG12 and Geobacillus sp. DUSELR7 on days 10 and 7, respectively [12]. Furthermore, Gupta et al. isolated several cellulose-degrading bacteria exhibiting CMCase activities in the range of $0.162-0.400 \mathrm{U} / \mathrm{mL}$ [13].

With regard to studies on optimization of cellulase production by aerobic bacteria, Deka et al. used response surface methodology and found that Bacillus subtilis AS3 exhibited a maximum CMCase activity of $0.43 \mathrm{U} / \mathrm{mL}$ [14]. Furthermore, using response surface methodology and orthogonal experiment design for medium optimization, Da Vinha et al. and Sheng et al. observed a maximum CMCase activity of 2.0 and $1.432 \mathrm{U} / \mathrm{mL}$ by Streptomyces viridobrunneus SCPE-09 and Pseudomonas sp. HP207, respectively $[15,16]$. Thus, isolation of aerobic bacterial strains producing higher cellulase activity is gaining increasing interest.

In this study, diverse aerobic bacteria capable of hydrolyzing cellulose were isolated from the subtropical region of China, with Burkholderia sp. being the most ubiquitous. Furthermore, a bacterial strain ME27-1, producing CMCase at $2.08 \mathrm{U} / \mathrm{mL}$ after optimization of culture conditions, was isolated and identified.

\section{Materials and Methods}

2.1. Collection of Soil Samples. The soil samples used in this study were collected from Maoer Mountain (Guilin City), Longgang (Chongzuo City), Dawang Ridge (Baise City), Huaping (Guilin City), Shankou Halodrymium (Beihai City) Natural Reserves, a starch factory in Fangchenggang City, a bagasse compost at the experimental farm of Guangxi University (Nanning City) in Guangxi Zhuang Autonomous Region, China, and Baima Snow Mountain Natural Reserve in Yunnan Province, China. The samples were taken from organic-rich soil.

2.2. Strain Isolation and Screening. The soil sample suspensions were inoculated on Czapek's medium [17] containing sugarcane bagasse pulp (in g/L: $\mathrm{NaNO}_{3}, 2 ; \mathrm{MgSO}_{4} \cdot 7 \mathrm{H}_{2} \mathrm{O}, 0.5$; $\mathrm{NaCl}, 0.5 ; \mathrm{FeSO}_{4} \cdot 7 \mathrm{H}_{2} \mathrm{O}, 0.01 ; \mathrm{KH}_{2} \mathrm{PO}_{4}, 1.0$; yeast extract, 0.4 ; pulp, 5 (containing 80\% water); and agar, 15.0; pH 5.0) and incubated at $28^{\circ} \mathrm{C}$. Subsequently, single colonies were picked 
TABLE 1: Cellulose-degrading bacteria isolated from different natural reserves of subtropical region in China.

\begin{tabular}{|c|c|c|c|c|c|c|}
\hline Strains & Location & $\begin{array}{l}D / d \\
(\mathrm{~mm})\end{array}$ & $\begin{array}{l}\text { CMCase activity } \\
(\mathrm{U} / \mathrm{mL})\end{array}$ & $\begin{array}{c}\text { Max } \\
\text { identity } \\
(\%)\end{array}$ & Strain of closest match & Identification \\
\hline BM17-1 & \multirow{3}{*}{$\begin{array}{l}\text { Baima Snow } \\
\text { Mountains }\end{array}$} & $24 / 1.9$ & ND & 99 & Burkholderia sp. bB24(JF772524) & Burkholderia \\
\hline BM19-6 & & $23 / 1.8$ & ND & 99 & Burkholderia sp. bB24(JF772524) & Burkholderia \\
\hline BM19-8 & & $25 / 2.3$ & ND & 99 & Burkholderia sp. bB24(JF772524) & Burkholderia \\
\hline BS16-3 & Dawang Ridge & $30 / 5$ & ND & 99 & Bacillus anthracis JN22(KF150341) & Bacillus \\
\hline DF2-1 & Nanning city & $31 / 2.7$ & ND & 99 & Bacillus subtilis 0-2 (FJ959367) & Bacillus \\
\hline FCD1-3 & \multirow{7}{*}{$\begin{array}{l}\text { Fangchenggang } \\
\text { city }\end{array}$} & $34 / 2$ & $0.06 \pm 0.002$ & 99 & Arthrobacter sp. Am13(KC853144) & Arthrobacter \\
\hline FCD2-1 & & $20 / 2.2$ & ND & 100 & Burkholderia cepacia ATCC 49709(AY741349) & Burkholderia \\
\hline FCD2-2 & & $25 / 2.4$ & ND & 99 & Enterobacter aerogenes T2(GU265554) & Enterobacter \\
\hline FCD3-5 & & $28 / 3$ & ND & 99 & Chryseobacterium sp. TS35(HQ647281) & Chryseobacterium \\
\hline FCD6-1 & & $20 / 2$ & ND & 99 & Burkholderia sp. D414(KF601211) & Burkholderia \\
\hline FCD7-2 & & $28 / 2.6$ & ND & 99 & Burkholderia sp. B26(KF788047) & Burkholderia \\
\hline FCD11-1 & & $24 / 1.5$ & ND & 99 & Arthrobacter woluwensis A12-1(AB244301) & Arthrobacter \\
\hline HPA16-1 & \multirow{3}{*}{ Huaping } & $24 / 2.5$ & ND & 98 & Pandoraea norimbergensis CCUG 39188(AY268174) & Pandoraea \\
\hline HPA21-1 & & $30 / 2.3$ & ND & 99 & Citrobacter freundii KUDC1770(KC355277) & Citrobacter \\
\hline HPC15-3 & & $25 / 2$ & ND & 98 & Citrobacter freundii KUDC1770(KC355277) & Citrobacter \\
\hline ME27-1 & \multirow{5}{*}{$\begin{array}{l}\text { Maoer } \\
\text { Mountains }\end{array}$} & $30 / 3$ & $0.17 \pm 0.005$ & 99 & Paenibacillus terrae AM141(AF391124) & Paenibacillus terrae \\
\hline ME43-1 & & $29 / 3.5$ & ND & 99 & Dyella sp. BM6(HM057825) & Dyella \\
\hline ME59-1 & & $29 / 2.7$ & ND & 99 & Burkholderia cepacia ATCC 21809(AY741338) & Burkholderia \\
\hline ME59-2 & & $26 / 2.5$ & ND & 99 & Burkholderia cepacia ATCC 21809(AY741338) & Burkholderia \\
\hline ME67-3 & & $31 / 3.4$ & ND & 99 & Pseudomonas sp. CK57(EU686687) & Pseudomonas \\
\hline NG5-2 & Longgang & $20 / 2$ & ND & 99 & Citrobacter freundii AtetA(KF245926) & Citrobacter \\
\hline SK3-4 & $\begin{array}{l}\text { Shankou } \\
\text { Halodrymium }\end{array}$ & $43 / 4.6$ & $0.01 \pm 0.001$ & 99 & Bacillus subtilis IARI-NIAW1-13(KF054916) & Bacillus \\
\hline
\end{tabular}

" $D / d$ ": hydrolyzed zone diameter/colony diameter on agar media containing CMC as sole carbon source; "ND": no detectable activity.

using an inoculating needle and inoculated onto Mandels and Reese medium [18] containing carboxymethyl cellulose sodium salt (CMC-Na; in g/L: $\mathrm{KH}_{2} \mathrm{PO}_{4}, 2.0 ;\left(\mathrm{NH}_{4}\right)_{2} \mathrm{SO}_{4}, 1.4$; $\mathrm{MgSO}_{4} \cdot 7 \mathrm{H}_{2} \mathrm{O}, 0.3 ; \mathrm{CaCl}_{2}, 0.3$; yeast extract, $0.4 ; \mathrm{FeSO}_{4} \cdot 7 \mathrm{H}_{2} \mathrm{O}$, 0.005; $\mathrm{MnSO}_{4}, 0.0016 ; \mathrm{ZnCl}_{2}, 0.0017 ; \mathrm{CoCl}_{2}, 0.002 ; \mathrm{CMC}-\mathrm{Na}$, 5.0; and agar, 15.0; pH 5.0). After incubation at $28^{\circ} \mathrm{C}$ for $48 \mathrm{~h}$, all the plates were stained with $1 \%(\mathrm{w} / \mathrm{v})$ Congo-red solution for $15 \mathrm{~min}$ and discolored with $1 \mathrm{M} \mathrm{NaCl}$ for $15 \mathrm{~min}$ [19]. The degradation zones were visible around the bacteria, showing that the strains could hydrolyze CMC.

The modified Mandels medium (also called basal medium) used for CMCase production by the isolates contained the following components (in $\mathrm{g} / \mathrm{L}: \mathrm{KH}_{2} \mathrm{PO}_{4}, 1.5$; $\mathrm{Na}_{2} \mathrm{HPO}_{4} \cdot 7 \mathrm{H}_{2} \mathrm{O}, 2.5 ;\left(\mathrm{NH}_{4}\right)_{2} \mathrm{SO}_{4}, 1.5 ; \mathrm{MgSO}_{4} \cdot 7 \mathrm{H}_{2} \mathrm{O}, 0.3$; $\mathrm{CaCl}_{2}, 0.1 ; \mathrm{FeSO}_{4} \cdot 7 \mathrm{H}_{2} \mathrm{O}, 0.005 ; \mathrm{MnSO}_{4}, 0.0016 ; \mathrm{ZnCl}_{2}$, 0.0017; and $\mathrm{CoCl}_{2}, 0.002 ; \mathrm{pH} 7.0$ ). The bacterial isolates were precultured overnight in general bacteria medium (in $\mathrm{g} / \mathrm{L}$ : beef extract, 2; yeast extract, 2; sucrose, 6; and peptone, 5) at $28^{\circ} \mathrm{C}$ and $180 \mathrm{rpm}$. Subsequently, $2 \mathrm{~mL}$ of the culture was inoculated into $250 \mathrm{~mL}$ conical flask containing $50 \mathrm{~mL}$ of basal medium with $10 \mathrm{~g} / \mathrm{L}$ of CMC-Na as the sole carbon source and incubated at $28^{\circ} \mathrm{C}$ and $180 \mathrm{rpm}$ for $60 \mathrm{~h}$.
2.3. Enzyme Assay. Enzyme production during cultivation was assayed at $12 \mathrm{~h}$ intervals up to 3 days. The cultures were centrifuged at $12,000 \mathrm{rpm}$ for $10 \mathrm{~min}$ at $4^{\circ} \mathrm{C}$. The supernatants were collected as crude enzyme for enzyme assay. CMCase, Avicel cellulase (Avicelase), and filter-paper cellulase (FPase) activities were determined using the 3,5-dinitrosalicylic acid (DNS) method [20]. The reaction systems were prepared as follows: $250 \mu \mathrm{L}$ of crude enzyme (appropriately diluted) mixed with $250 \mu \mathrm{L}$ of $2 \%(\mathrm{w} / \mathrm{v}) \mathrm{CMC}$ for determining the CMCase activity; $500 \mu \mathrm{L}$ of enzyme mixed with $1 \mathrm{~mL}$ of Avicel $(1 \%, \mathrm{w} / \mathrm{v})$ for determining the Avicelase activity; and $500 \mu \mathrm{L}$ of enzyme mixed with $50 \mathrm{mg}$ of Whatman number 1 filter paper $(1.0 \times 6.0 \mathrm{~cm})$ in $1 \mathrm{~mL}$ of buffer for determining the FPase activity. The buffer used for dissolving or resuspending the substrates was $100 \mathrm{mM}$ sodium citrate buffer ( $\mathrm{pH}$ 5.5). The mixtures were incubated at $50^{\circ} \mathrm{C}$ for $30 \mathrm{~min}$ for CMCase assay and for $1 \mathrm{~h}$ for Avicelase and FPase assay, respectively. Then, the reactions were stopped by adding $1 \mathrm{~mL}$ of DNS reagent for CMCase assay and $3 \mathrm{~mL}$ of DNS reagent for Avicelase and FPase assay, respectively. All the mixtures were heated in boiling water for $5 \mathrm{~min}$ for color development. Subsequently, $200 \mu \mathrm{L}$ of each sample was transferred to 96 -well microplate 


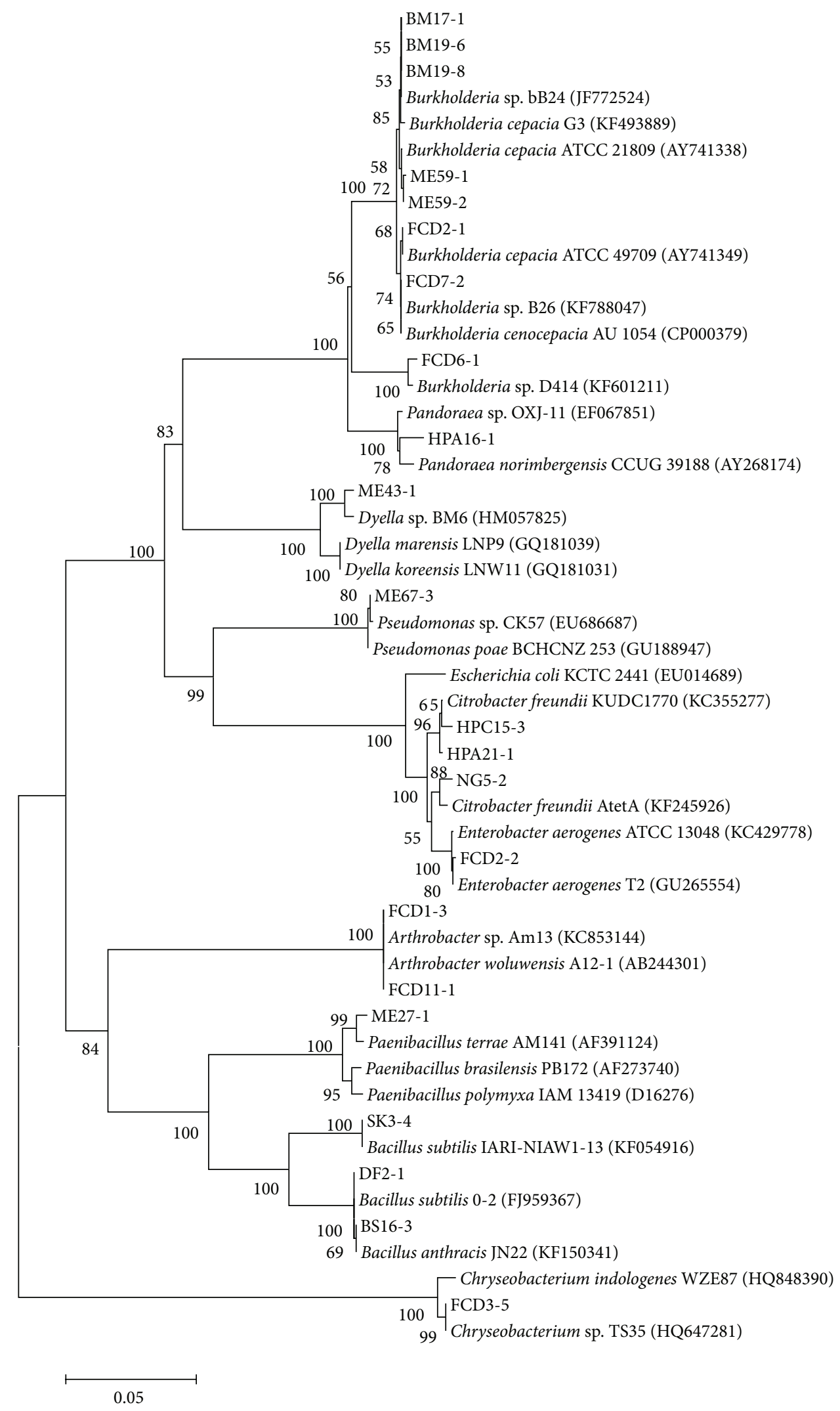

FIGURE 2: Phylogenetic tree for the 22 strains and related bacterial strains. The accession numbers of the strains are given in brackets. 
TABLE 2: Physiological and biochemical properties of strain ME27-1.

\begin{tabular}{|c|c|}
\hline Characteristics & Reaction \\
\hline Motility & + \\
\hline Catalase & + \\
\hline $\mathrm{H}_{2} \mathrm{~S}$ production & - \\
\hline Nitrate reduction & + \\
\hline \multicolumn{2}{|l|}{ Hydrolyzing ability } \\
\hline Starch & + \\
\hline Gelatin & + \\
\hline \multicolumn{2}{|l|}{ Acid fermentation } \\
\hline Glycerol & - \\
\hline Ribose & + \\
\hline$\beta$-Methyl-D-xyloside & - \\
\hline Mannose & + \\
\hline Inositol & - \\
\hline$\alpha$-Methyl-glucoside & + \\
\hline Esculin & + \\
\hline Lactose & + \\
\hline Synanthrin & - \\
\hline Glycogen & + \\
\hline D-Lyxose & - \\
\hline $\mathrm{D}(\mathrm{L})$-Arabitol & - \\
\hline 5-Keto-gluconate & - \\
\hline Erythritol & - \\
\hline D-Xylose & + \\
\hline Galactose & - \\
\hline Sorbose & - \\
\hline Mannitol & - \\
\hline N-Acetyl-glucosamine & - \\
\hline Salicine & + \\
\hline Melibiose & + \\
\hline Melezitose & - \\
\hline Xylitol & - \\
\hline D-Tagatose & - \\
\hline D-Arabinose & - \\
\hline L-Xylose & + \\
\hline Glucose & - \\
\hline Rhamnose & - \\
\hline Sorbitol & - \\
\hline Amygdalin & + \\
\hline Cellobiose & + \\
\hline Sucrose & + \\
\hline Raffinose & + \\
\hline Gentiobiose & + \\
\hline D-Fucose & - \\
\hline Gluconate & - \\
\hline L-Arabinose & + \\
\hline Adonitol & - \\
\hline Fructose & + \\
\hline Dulcitol & - \\
\hline$\alpha$-Methyl-D-xyloside & - \\
\hline Arbutin & + \\
\hline
\end{tabular}

TABLE 2: Continued.

\begin{tabular}{lc}
\hline Characteristics & Reaction \\
\hline Maltose & + \\
Trehalose & + \\
Starch & + \\
D-Turanose & - \\
L-Fucose & - \\
2-Keto-gluconate & - \\
\hline “+": positive reaction; “-": negative reaction. &
\end{tabular}

and the absorbance was measured at $540 \mathrm{~nm}[21,22]$. One unit $(\mathrm{U})$ of the enzyme activity was defined as the amount of enzyme that released $1 \mu \mathrm{mol}$ of reducing sugars equivalent to glucose per minute during the reaction.

The activity of $\beta$-glucosidase was measured by using $p$ nitrophenyl- $\beta$-D-glucopyranoside (p-NPG) as substrate. The enzyme activity was determined by detecting the amount of $p$-nitrophenol ( $\mathrm{p}-\mathrm{NP})$ produced from p-NPG [23]. One unit (U) of $\beta$-glucosidase activity was defined as the amount of enzyme liberating $1 \mu \mathrm{mol}$ of $\mathrm{p}-\mathrm{NP}$ per minute.

2.4. $16 S$ rRNA Gene Sequencing and Phylogenetic Analysis of the CMC-Degrading Isolates. The CMC-degrading isolates were cultivated in general bacteria medium at $28^{\circ} \mathrm{C}$ for $24 \mathrm{~h}$. The culture was directly used for the amplification of bacterial $16 \mathrm{~S}$ rRNA gene by PCR [24]. Two universal 16S rRNA gene primers (F27: $5^{\prime}$-AGAGTTTGATCCTGGCTCAG- $3^{\prime}$ and R1492: $5^{\prime}$-TACGGTTACCTTGTTACGACTT- $3^{\prime}$ ) were used [25]. The $25 \mu \mathrm{L}$ mixtures were composed of $1 \mu \mathrm{L}$ of bacterial culture as template DNA, $12.5 \mu \mathrm{L}$ of $2 \times$ Taq PCR Master Mix (containing $0.5 \mathrm{U}$ Taq DNA polymerase $/ \mu \mathrm{L}, 500 \mu \mathrm{M}$ of each dNTP, $20 \mathrm{mM}$ Tris- $\mathrm{HCl}$ ( $\mathrm{pH} 8.3$ ), $100 \mathrm{mM} \mathrm{KCl,} 3 \mathrm{mM}$ $\mathrm{MgCl}_{2}$, and bromophenol blue, purchased from Tiangen Biotech, Beijing, China), $1 \mu \mathrm{L}$ of each primer $(10 \mu \mathrm{M})$, and $9.5 \mu \mathrm{L}$ of double-distilled $\mathrm{H}_{2} \mathrm{O}$. The PCR procedure employed was as follows: primary denaturation for $5 \mathrm{~min}$ at $94^{\circ} \mathrm{C} ; 30$ cycles of denaturation at $94^{\circ} \mathrm{C}$ for $30 \mathrm{~s}$; annealing at $55^{\circ} \mathrm{C}$ for $30 \mathrm{~s}$, and extension at $72^{\circ} \mathrm{C}$ for $100 \mathrm{~s}$; and an additional reaction for $10 \mathrm{~min}$ at $72^{\circ} \mathrm{C}$. The PCR products were detected on $0.8 \%$ agarose gel to confirm its purity, quantity, and size. The PCR products were sent to Sangon Biotech (Shanghai) Co., Ltd., China, for sequencing.

The 16S rRNA gene sequences were compared with other $16 \mathrm{~S}$ rRNA gene sequences available in GenBank by using the BLASTN program (http://blast.ncbi.nlm.nih.gov/Blast.cgi) and aligned with similar sequences by using CLUSTX program. The phylogenetic tree was constructed by applying the neighbor-joining method using MAGA4.1 program based on Kimura-2 parameters with 1000 replicates of bootstrap values [26].

2.5. Morphological, Physiological, and Biochemical Identification of the Bacterial Strain ME27-1. The morphological properties of the strain ME27-1, including shape, size, colony characteristics (color, shape, surface, elevation, and edge), and Gram staining were evaluated [27]. The physiological and 


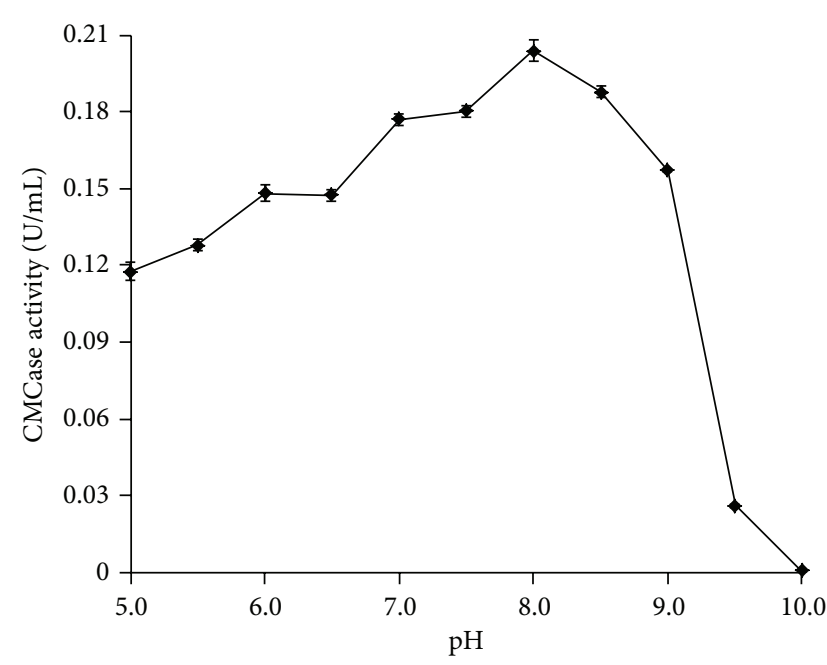

(a)

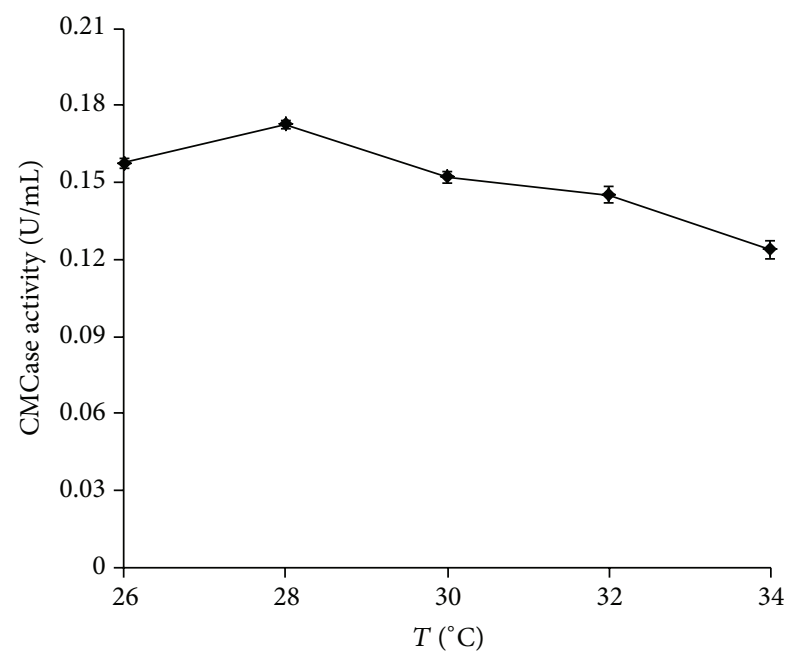

(b)

FIGURE 3: Effect of initial $\mathrm{pH}$ and temperature on enzyme production by the strain ME27-1. (a) Initial pH. (b) Temperature (T).

biochemical characterization of the strain ME27-1 was carried out by using API 50CHB microtests (bioMérieux).

2.6. Optimization of Cultivation Conditions for CMCase Production by the Strain ME27-1. The effect of initial $\mathrm{pH}$ and temperature on CMCase production by the strain ME27-1 was determined by cultivating the strain in $50 \mathrm{~mL}$ of basal medium containing $10 \mathrm{~g} / \mathrm{L}$ of CMC-Na at various $\mathrm{pH}$ (ranging from 5.0 to 10.0 with an interval of 0.5$)$ and temperatures (26$34^{\circ} \mathrm{C}$ ) for $60 \mathrm{~h}$ at $180 \mathrm{rpm}$.

The effect of carbon and nitrogen sources on cellulase production by the strain ME27-1 was determined by using 11 different carbon sources (fructose, glucose, glycerol, lactose, sucrose, maltose, CMC-Na, filter paper (chopped into 20 mesh size), Avicel, soluble starch, and wheat bran which was chopped into 80 mesh size) and 10 different nitrogen sources as below: $\left(\mathrm{NH}_{4}\right)_{2} \mathrm{SO}_{4}, \mathrm{NH}_{4} \mathrm{NO}_{3}, \mathrm{NaNO}_{3}, \mathrm{KNO}_{3}$, $\mathrm{NH}_{4} \mathrm{Cl}$, urea, soybean, yeast extract, tryptone, and beef extract. The carbon sources were used at a concentration of $10 \mathrm{~g} / \mathrm{L}$, instead of the carbon source in the basal medium. Furthermore, different concentrations (10-100 g/L with an interval of $10 \mathrm{~g} / \mathrm{L}$ ) of optimal carbon source were examined. Similarly, the effect of nitrogen sources was also studied with an initial concentration of $1.5 \mathrm{~g} / \mathrm{L}$.

The effect of different inoculum sizes $(2 \%, 4 \%, 6 \%, 8 \%$, and $10 \%)$ on enzyme production was tested. All media were in $\mathrm{pH}$ 8.0. All the flasks were incubated at $28^{\circ} \mathrm{C}$. The CMCase activity was detected at an interval of $12 \mathrm{~h}$.

2.7. Properties of CMCase Produced by the Bacterial Strain ME27-1. To determine the optimal $\mathrm{pH}, 250 \mu \mathrm{L}$ of crude CMCase supernatant was incubated with $250 \mu \mathrm{L}$ of CMC-Na $(2 \%, \mathrm{w} / \mathrm{v})$ at $50^{\circ} \mathrm{C}$ and different $\mathrm{pH}(3.0-11.0$ with an interval of 0.5$)$, respectively. To observe the effect of temperature, CMCase was incubated with $2 \% \mathrm{CMC}-\mathrm{Na}$ at a $\mathrm{pH}$ of 5.5 and temperature ranging from 30 to $75^{\circ} \mathrm{C}$ with an interval of $5^{\circ} \mathrm{C}$.
The maximum CMCase activity obtained at different $\mathrm{pH}$ and temperatures was considered to be $100 \%$.

The effect of $\mathrm{pH}$ on the stability of CMCase was studied by mixing the crude enzyme with different buffers $(1: 9, \mathrm{v} / \mathrm{v})$ with $\mathrm{pH}$ ranging from 3.0 to 10.0 . The CMCase activity of the crude enzyme after incubating at $4^{\circ} \mathrm{C}$ for $24 \mathrm{~h}$ at different $\mathrm{pH}$ was detected. To study the thermostability of the CMCase produced by the strain ME27-1, the crude enzyme was preincubated at different temperatures (varying from 30 to $75^{\circ} \mathrm{C}$ with an interval of $5^{\circ} \mathrm{C}$ ) for $1 \mathrm{~h}$. The residual CMCase activity was detected. The maximum CMCase activity obtained at $\mathrm{pH}$ $3.0-10.0$ or temperature $30-75^{\circ} \mathrm{C}$ was considered to be $100 \%$. All the enzyme assays were carried out in triplicate.

2.8. Nucleotide Sequence Accession Numbers. All the DNA sequences of the partial 16S rRNA genes of the 22 strains reported in this study have been deposited into the GenBank database under the accession numbers from KF536877 to KF536898.

\section{Results and Discussion}

3.1. Isolation and Screening of Cellulose-Degrading Bacteria. A total of 245 cellulose-degrading aerobic bacterial strains were isolated from different natural reserves in the subtropical region of China, which were cultured in agar medium containing sugarcane bagasse pulp as the sole carbon source. Out of these strains, 22 isolates showed hydrolyzing zones on agar plates containing CMC-Na after Congo-red staining (Figure 1). The hydrolyzing zone diameter and colony diameter are listed in Table 1.

Among the 22 isolates, only three isolates (ME27-1, FCD13 , and SK3-4) were found to produce measurable CMCase after liquid cultivation, and isolate ME27-1 showed the highest CMCase activity $(0.17 \mathrm{U} / \mathrm{mL})$ after incubation for $60 \mathrm{~h}$ in basal liquid medium containing $10 \mathrm{~g} / \mathrm{L}$ of CMC-Na (Table 1). The CMCase activity of the other 19 strains was undetectable 


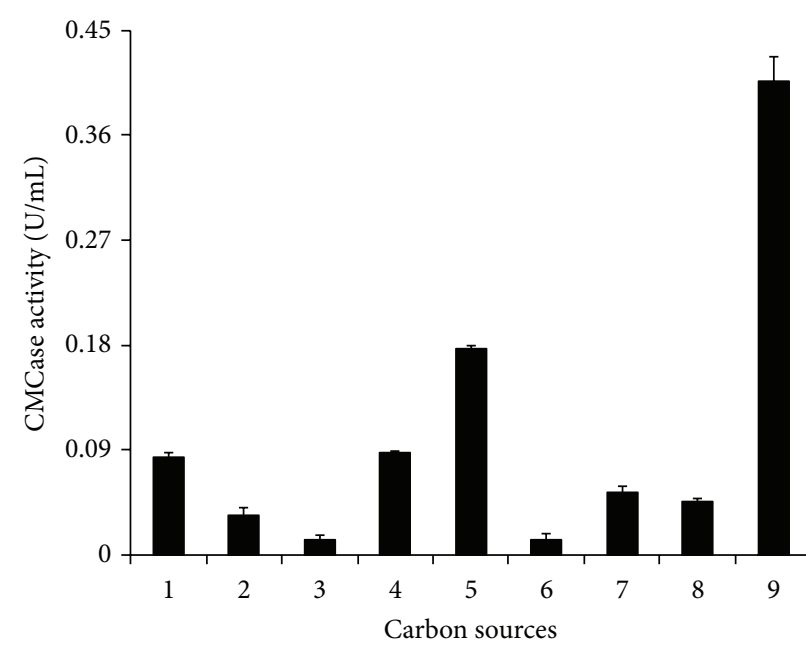

(a)

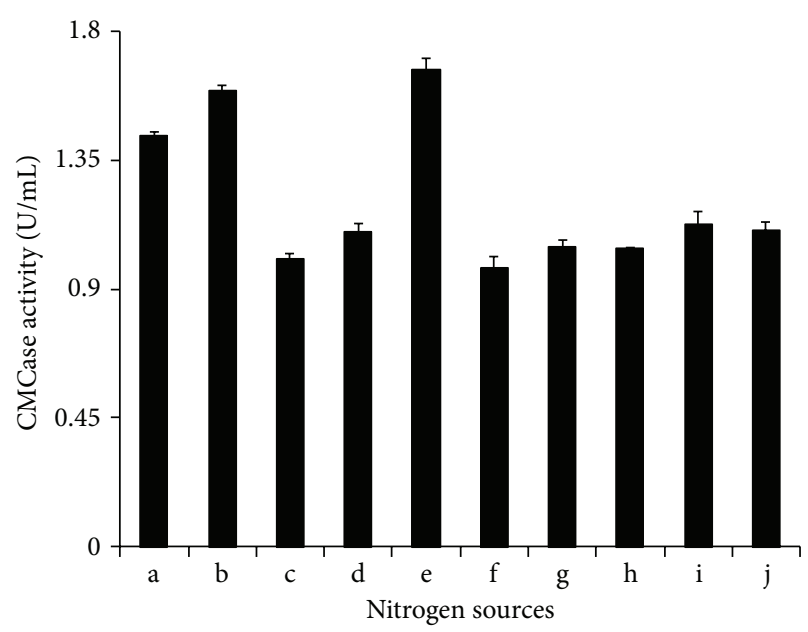

(c)

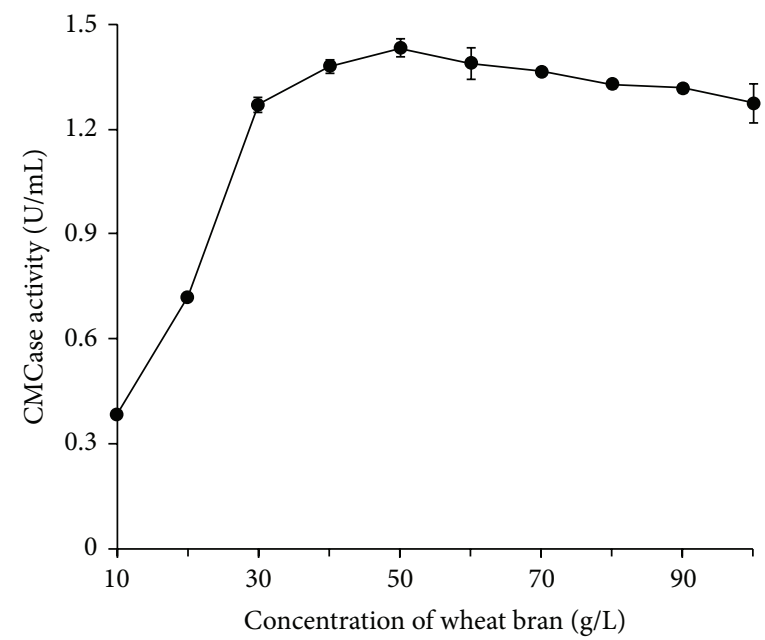

(b)

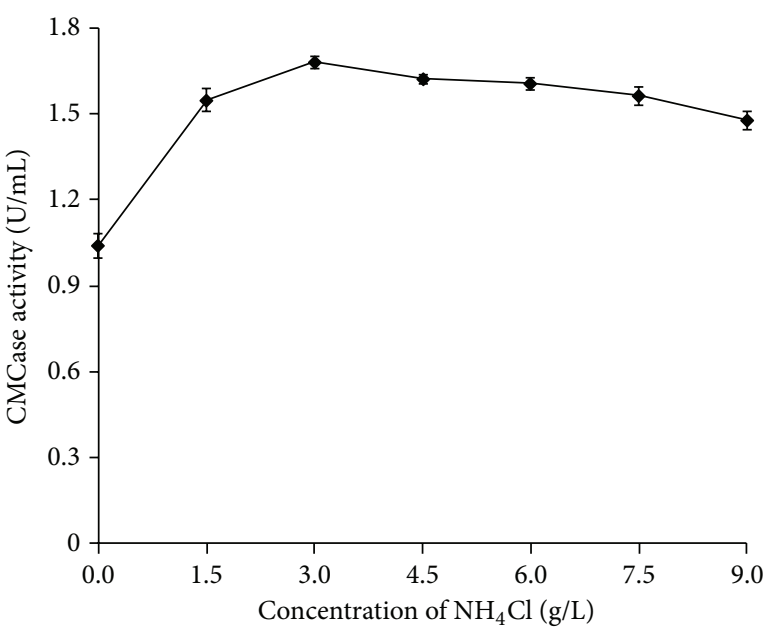

(d)

FIGURE 4: Effect of carbon and nitrogen sources on CMCase production by the strain ME27-1. (a) Different carbon sources: $1 \sim 9$ represented glycerol, lactose, sucrose, maltose, CMC-Na, filter paper, Avicel, soluble starch, and wheat bran, respectively. (b) The concentration of wheat bran. (c) Different nitrogen sources: a j represented $\left(\mathrm{NH}_{4}\right)_{2} \mathrm{SO}_{4}, \mathrm{NH}_{4} \mathrm{NO}_{3}, \mathrm{NaNO}_{3}, \mathrm{KNO}_{3}, \mathrm{NH}_{4} \mathrm{Cl}$, urea, soybean, yeast extract, tryptone, and beef extract, respectively. (d) The concentration of $\mathrm{NH}_{4} \mathrm{Cl}$.

after cultivating in various liquid media for up to 6 days, and the Avicelase, FPase, and $\beta$-glucosidase activities of all the 22 bacterial strains were also undetectable.

Congo-red staining has been widely used in many studies for screening cellulose-degrading microorganisms. Although Teather and Wood described the relationship between the diameter of hydrolyzing zone and log enzyme concentration, this correlation could not represent the enzyme-producing ability of the microorganisms [19]. In the present study, although some strains presented large and clear hydrolyzing zones, the activities of CMCase and other cellulases produced by them were undetectable in various liquid media containing $\mathrm{CMC}$ and other cellulosic materials, suggesting that either the concentration of the enzyme produced by these strains was very low to be detected after cultivation in liquid medium or the ability of the strains to secrete CMCase was weak. Sadhu and Maiti also reported that the diameter of the hydrolyzing zone may not accurately reflect the real cellulase activity [28].

In general, aerobic bacteria produce low levels of Avicelase, FPase, and $\beta$-glucosidase. In a study carried out by Rastogi et al., Brevibacillus sp. DUSELG12 and Geobacillus sp. DUSELR7 were found to produce a maximum FPase activity of 0.027 and $0.043 \mathrm{U} / \mathrm{mL}$ on days 7 and 8 , respectively [12]. Recently, Soares et al. found that only $9.1 \%$ of bacterial strains were able to degrade Avicel on agar plates [7].

3.2. Identification of Cellulose-Degrading Bacteria. The DNA fragments containing partial $16 \mathrm{~S}$ rRNA genes of the 22 isolates were amplified and sequenced. The sequences obtained were matched with those available in GenBank, which revealed maximum identity of these isolates and allowed identification of these cellulose-degrading bacterial strains (Table 1). 


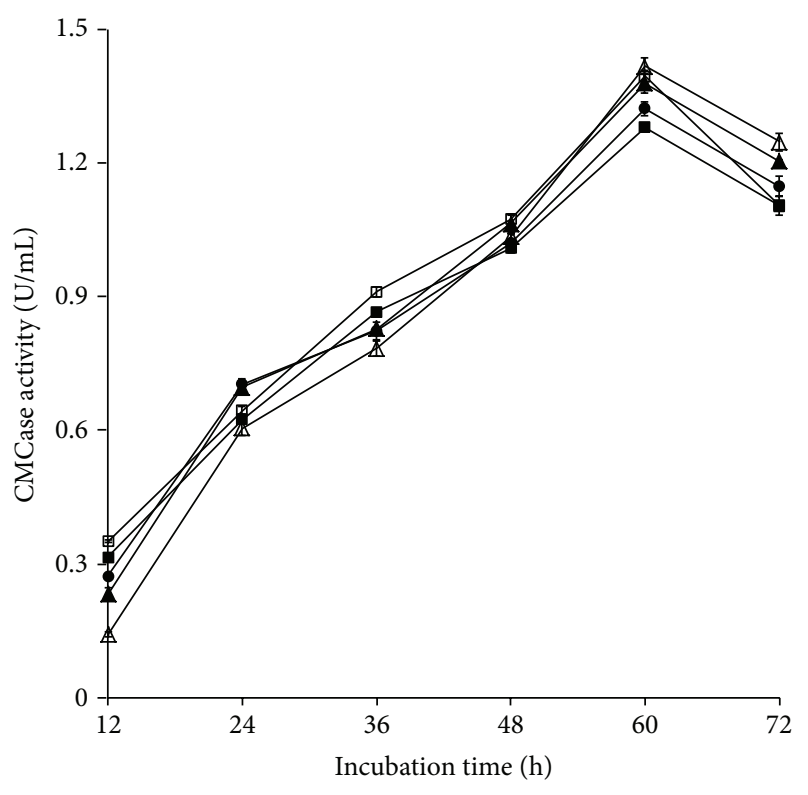

FIGURE 5: Effect of inoculum size and incubation period on CMCase production by the strain ME27-1. 2\% (empty triangle); $\%$ (filled triangle); $6 \%$ (filled circle); $8 \%$ (filled square); and 10\% (empty square). Error bars show the standard deviation of experimental point $(n=$ $3)$.

It was found that the 22 aerobic bacterial strains that could hydrolyze cellulose belonged to 10 different genera: Burkholderia (36.36\%), Bacillus (13.65\%), Citrobacter (13.65\%), Arthrobacter (9.10\%), Enterobacter (4.54\%), Chryseobacterium (4.54\%), Pandoraea (4.54\%), Paenibacillus (4.54\%), Dyella (4.54\%), and Pseudomonas (4.54\%). The phylogenetic tree of the 22 strains was constructed by using MAGA4.1 program (Figure 2).

Various cellulose-degrading bacteria have been found in different environments. The genus Burkholderia was observed to be the main cellulose-hydrolyzing bacteria and was considered to play an important role in cellulose degradation in the subtropical region of China in this study. In addition, bacteria belonging to the genera Arthrobacter, Chryseobacterium, Pandoraea, and Dyella were also found to be cellulolytic in the present study, which have been rarely reported as cellulose-degrading bacteria. In a previous study, Lo et al. reported that the cellulase-producing bacterial strains isolated from a rice field in southern Taiwan mainly belonged to the genus Cellulomonas [9]. On the other hand, Bacillus was reported to be the dominant cellulose-degrading bacteria in samples collected from paper mill sludges and organic fertilizers from Red Rock, Canada, as well as in those from soil, compost, and animal waste slurry from Jeju Island $[29,30]$. Similarly, Burkholderia was found to be the main genus of cellulase-producing bacteria in the subtropical rainforest in Okinawa Island, Japan [31].

The strain ME27-1, with higher CMCase activity, was thoroughly examined. The partial $16 \mathrm{~S}$ rRNA gene (1309 bp) from the strain ME27-1 showed a maximum identity of $99 \%$ with that of Paenibacillus terrae $\mathrm{AM}_{141}{ }^{\mathrm{T}}$ (T: type strain). Morphological tests revealed that the cells of the strain ME27-1 were rod-shaped, endospore-forming, Gram-positive, and $0.8 \times 1.9-3.2 \mu \mathrm{m}$ in size. The appearance of the colony on the TSA medium was cream-colored, moist, irregular, swollen, and pigment-free. The biochemical properties of the strain ME27-1 are listed in Table 2. The morphological, physiological, and biochemical properties of the strain ME271 were found to be mostly similar to those of P. terrae [27]. Thus, the strain ME27-1 was identified as P. terrae.

To our knowledge, till date, no study has reported about CMCase production by $P$. terrae, although other species of Paenibacillus have been found to produce cellulase. Some CMCase genes cloned from Paenibacillus polymyxa GS01, Paenibacillus barcinonensis, Paenibacillus xylanilyticus KJ03, and Paenibacillus cookii SS-24 have been expressed in Escherichia coli and Saccharomyces cerevisiae [32-35]. On the other hand, CMCases from Paenibacillus curdlanolyticus B-6, Paenibacillus campinasensis BL11, Paenibacillus sp. B39, and P. polymyxa have been purified [36-39].

3.3. Effect of Initial pH, Temperature, Carbon and Nitrogen Sources, Inoculum Size, and Incubation Time on CMCase Production by $P$. terrae ME27-1. The best incubation conditions were $\mathrm{pH} 8.0$ and $28^{\circ} \mathrm{C}$ (Figures $3(\mathrm{a})$ and $3(\mathrm{~b})$ ). The CMCase activity declined when the initial $\mathrm{pH}$ and incubation temperature were not optimal. There have been diverse reports on the optimal initial $\mathrm{pH}$ and temperature for cellulolytic enzyme production by Paenibacillus sp. In a previous study, P. curdlanolyticus B-6 was cultivated for enzyme production at $\mathrm{pH} 7.0$ and $37^{\circ} \mathrm{C}$ [5]. Furthermore, Kumar et al. reported that the optimal initial $\mathrm{pH}$ and temperature for CMCase production by $P$. polymyxa were 5.5 and $37^{\circ} \mathrm{C}$, respectively [39]. Yoon et al. accounted that the optimal growth temperature for $P$. terrae was $30^{\circ} \mathrm{C}$, which is similar to that observed for optimal CMCase production by the strain ME27-1 [27].

Various cellulosic materials have been used to induce microorganisms to produce cellulase. When fructose and glucose were used as the sole carbon source, no CMCase activity was detected. Wheat bran induced the highest CMCase activity, which was about 2.5-fold higher than that observed in the basal medium containing CMC-Na (Figure 4(a)). The optimal concentration of wheat bran in the medium was found to be $50 \mathrm{~g} / \mathrm{L}$ (Figure 4(b)). Da Vinha et al. used steampretreated sugarcane bagasse (or wheat bran) as the main carbon source and found that wheat bran was the best inducer for CMCase production by S. viridobrunneus SCPE-09 [15]. Gao et al. demonstrated that rice bran was the optimal carbon source for CMCase production by Cellulophaga lytica LBH14, while Kumar et al. reported that high CMCase production by $P$. polymyxa was obtained when using mango peel as substrate $[39,40]$. In addition, wheat straw, rice straw, and xylan have been reported to be good carbon sources for CMCase production by Cellulomonas sp. and Cellulosimicrobium cellulans $[9,41]$.

Furthermore, maximum CMCase activity was noted when using $\mathrm{NH}_{4} \mathrm{Cl}$ as the sole nitrogen source (Figure 4(c)), and the best concentration of $\mathrm{NH}_{4} \mathrm{Cl}$ in the medium was observed to be $3 \mathrm{~g} / \mathrm{L}$ (Figure $4(\mathrm{~d})$ ). Many reports have shown that organic nitrogen sources are better than inorganic 


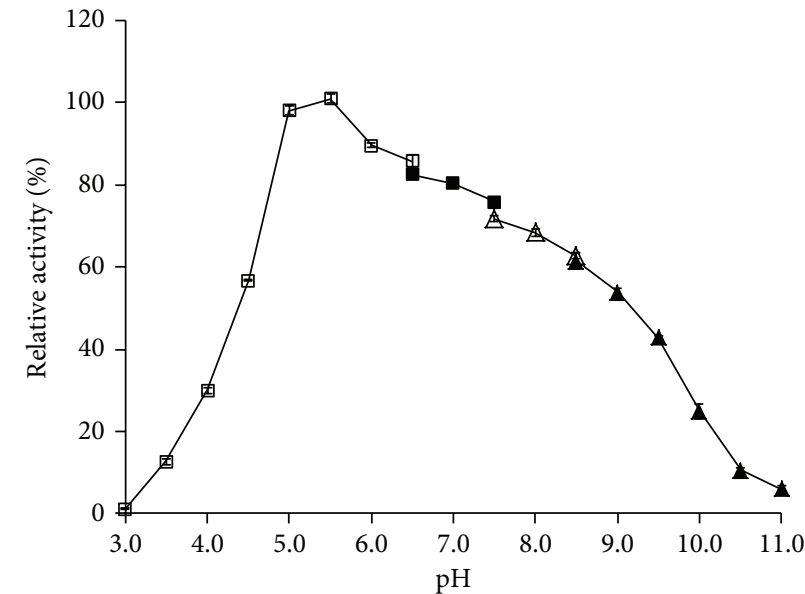

(a)

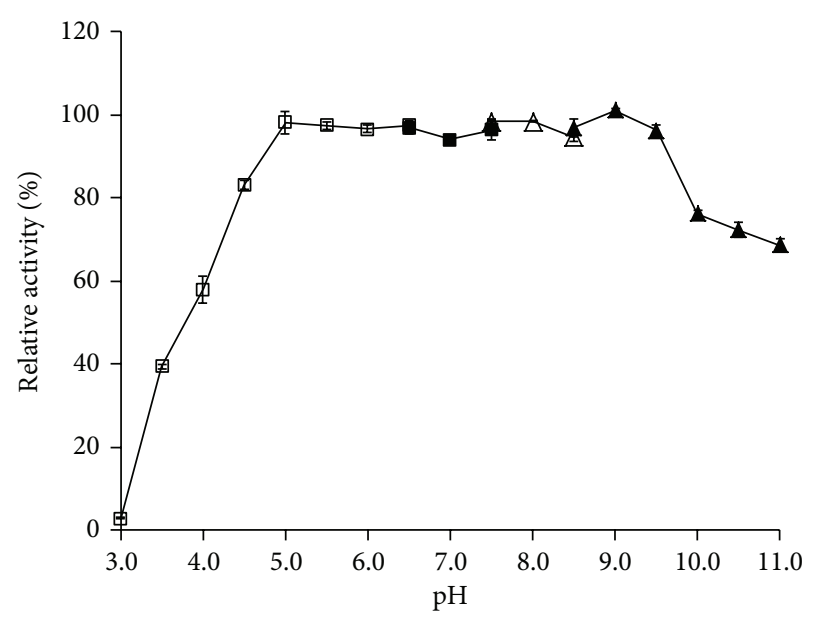

(c)

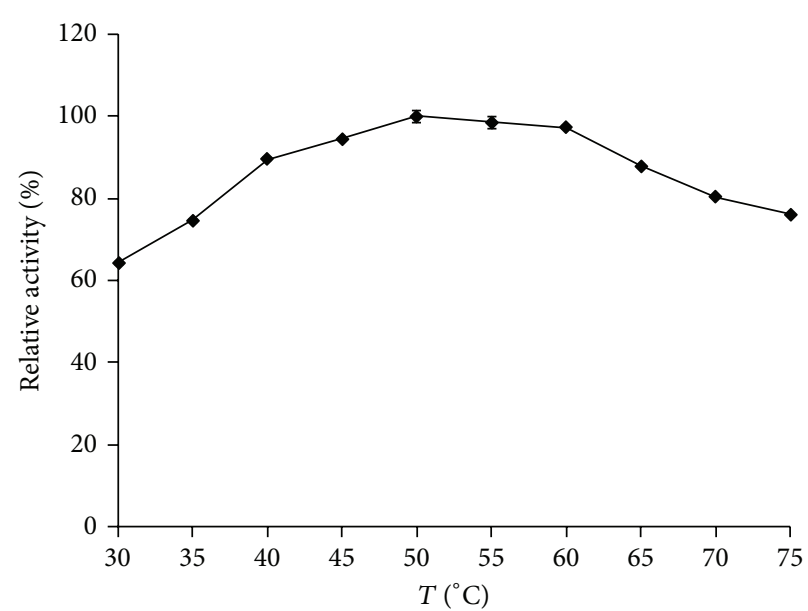

(b)

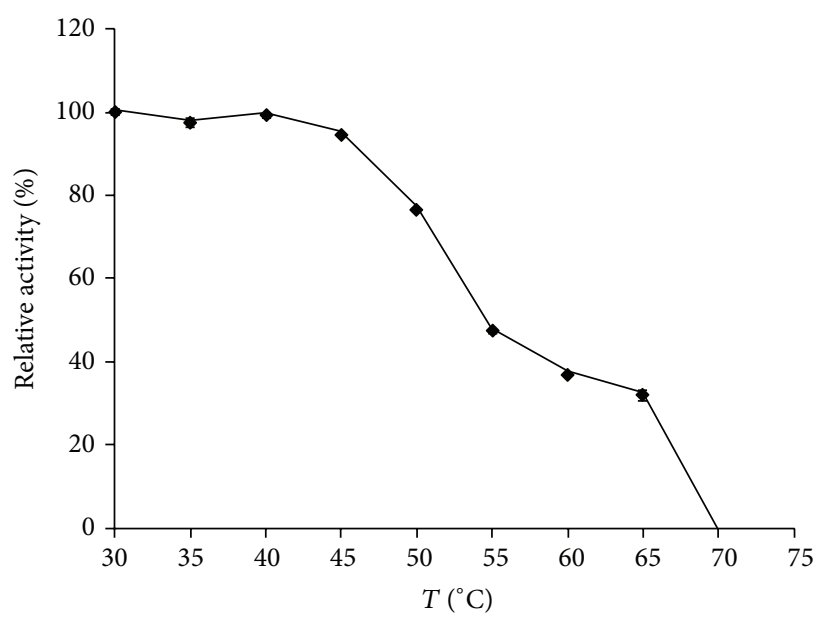

(d)

Figure 6: Properties of CMCase produced by the strain ME27-1. (a) Effect of pH on CMCase activity. (b) Effect of temperature on CMCase activity. (c) Effect of $\mathrm{pH}$ on the stability of CMCase. (d) Thermostability of CMCase. The different buffers used are as follows (100 mM): sodium citrate buffer (empty square; $\mathrm{pH} 3.0-6.5$ ), $\mathrm{Na}_{2} \mathrm{HPO}_{4}-\mathrm{NaH}_{2} \mathrm{PO}_{4}$ buffer (filled square; $\mathrm{pH}$ 6.5-7.5), Tris- $\mathrm{HCl}$ buffer (empty triangle; $\mathrm{pH}$ 7.5-8.5), and glycine- $\mathrm{NaOH}$ buffer (filled triangle; $\mathrm{pH} 8.5-11.0)$. Error bars show the standard deviation of experimental point $(n=2)$.

nitrogen sources $[15,16,42,43]$. In the present study, the CMCase activity of the strain ME27-1 was higher when inorganic nitrogen sources were used as the sole nitrogen source. Likewise, Kumar et al. and Kalogeris et al. also observed a similar phenomenon in their studies $[39,44]$.

In addition, use of an inoculum size of $2 \%$ resulted in maximum CMCase activity after incubation of the strain for $60 \mathrm{~h}$ (Figure 5). There has been increasing interest in cellulase-producing bacteria because of their ability to grow fast [45]. In the present study, the strain ME27-1 produced the highest CMCase activity after $60 \mathrm{~h}$ of incubation. On the other hand, in previous studies, maximum CMCase activity of Pseudomonas sp. HP207 and S. viridobrunneus SCPE-09 was observed after 24 and $48 \mathrm{~h}$ of incubation, respectively, which is much earlier than that noted for the strain ME27$1[15,16]$. However, different results have been reported in various studies. Maximum CMCase activity of $C$. lytica LBH14 was obtained after $72 \mathrm{~h}$ of incubation, whereas that of
Brevibacillus sp. DUSELG12 and Geobacillus sp. DUSELR7 was noted after days 9 and 7 , respectively $[12,40]$.

3.4. Properties of CMCase Produced by P. terrae ME27-1. The optimum $\mathrm{pH}$ and temperature of CMCase produced by strain ME27-1 were found to be 5.5 and $50^{\circ} \mathrm{C}$, respectively (Figures 6(a) and 6(b)). The CMCase produced by the strain ME27-1 was stable from pH 4.0 to 11.0, with more than $60 \%$ CMCase activity being retained (Figure 6(c)). Furthermore, the enzyme maintained $65 \%$ activity after incubation at $4^{\circ} \mathrm{C}$ and $\mathrm{pH} 11.0$ for $24 \mathrm{~h}$. The temperature profiles demonstrated that more than 95\% CMCase activity was retained at 30$45^{\circ} \mathrm{C}$ for $1 \mathrm{~h}$ (Figure $6(\mathrm{~d})$ ). However, the enzyme activity was reduced at temperatures above $50^{\circ} \mathrm{C}$. In fact, approximately $77 \%$ residual activity was maintained after preincubating the enzyme at $50^{\circ} \mathrm{C}$ for $1 \mathrm{~h}$.

Similar results were observed for cellulases produced by $S$. viridobrunneus SCPE-09 and P. cookii SS-24, with an optimal 
TABLE 3: Comparison of CMCase production by Paenibacillus terrae ME27-1 with other bacterial and fungal strains.

\begin{tabular}{|c|c|c|c|c|c|}
\hline Strains & Carbon source & Nitrogen source & Aerobic/anaerobic & $\begin{array}{c}\text { CMCase activity } \\
(\mathrm{U} / \mathrm{mL})\end{array}$ & Ref. \\
\hline P. terrae ME27-1 & Wheat bran & $\mathrm{NH}_{4} \mathrm{Cl}$ & Aerobic & 2.08 & This study \\
\hline Acinetobacter anitratus & CMC & $\left(\mathrm{NH}_{4}\right)_{2} \mathrm{SO}_{4}$ & Aerobic & 0.48 & {$[11]$} \\
\hline Branhamella sp. & $\mathrm{CMC}$ & $\left(\mathrm{NH}_{4}\right)_{2} \mathrm{SO}_{4}$ & Aerobic & 2.56 & {$[11]$} \\
\hline Bacillus subtilis AS3 & $\mathrm{CMC}$ & Peptone, yeast extract & Aerobic & 0.43 & {$[14]$} \\
\hline B. pumilus EWBCM1 & Galactose & Malt extract, $\mathrm{H}_{8} \mathrm{MoN}_{2} \mathrm{O}_{4}$ & Aerobic & 0.58 & [49] \\
\hline B. pumilus BpCRI 6 & CMC, glycerol & Tryptone & Aerobic & 1.90 & {$[50]$} \\
\hline Pseudomonas sp. HP207 & $\mathrm{CMC}-\mathrm{Na}$ & Yeast extract & Aerobic & 1.43 & {$[16]$} \\
\hline Streptomyces viridobrunneus SCPE-09 & Wheat bran & Corn steep liquid & Aerobic & 2.00 & {$[15]$} \\
\hline S. drozdowiczii & CMC & Yeast extract & Aerobic & 0.59 & {$[51]$} \\
\hline Streptomyces sp. J2 & Starch, glucose & $\mathrm{NH}_{4} \mathrm{Cl}$ & Aerobic & 0.43 & {$[52]$} \\
\hline Streptomyces sp. SLBA-08 & Sisal bagasse & $\left(\mathrm{NH}_{4}\right)_{2} \mathrm{SO}_{4}$ & Aerobic & 1.11 & {$[53]$} \\
\hline S. griseoaurantiacus ZQBC691 & CMC & $\left(\mathrm{NH}_{4}\right)_{2} \mathrm{SO}_{4}$ & Aerobic & 37.38 & {$[54]$} \\
\hline Clostridium thermocellum YM4 & Solka floe & $\mathrm{NH}_{4} \mathrm{Cl}$ & Anaerobic & 6.70 & {$[55]$} \\
\hline C. thermocopriae JT3-3 & Cellulose MN300 & Yeast extract, urea & Anaerobic & 4.53 & {$[56]$} \\
\hline C. papyrosolvens CFR-703 & Cellulose & Yeast extract & Anaerobic & 45.00 & {$[57]$} \\
\hline Geobacillus sp. T1 & Barley straw & $\mathrm{NH}_{4} \mathrm{Cl}$ & Aerobic & 143.50 & {$[58]$} \\
\hline Chaetomium globosum 414 & OPEFB & Peptone & Aerobic & 30.80 & [59] \\
\hline Chalara paradoxa $\mathrm{CH} 32$ & Glucose & Malt extract, yeast extract & Aerobic & 0.25 & {$[60]$} \\
\hline Aspergillus awamori 2B.361 U2/1 & Wheat bran & Yeast extract, $\mathrm{NaNO}_{3}$ & Aerobic & 4.90 & {$[61]$} \\
\hline Trichoderma reesei $\mathrm{RUT}-\mathrm{C} 30$ & Wheat bran & Yeast extract, $\mathrm{NaNO}_{3}$ & Aerobic & 20.00 & {$[61]$} \\
\hline Penicillium janthinellum NCIM 1171 & CP-123 & $\left(\mathrm{NH}_{4}\right)_{2} \mathrm{SO}_{4}$ & Aerobic & 111.80 & {$[62]$} \\
\hline T. viride NCIM 1051 & CP-123 & $\left(\mathrm{NH}_{4}\right)_{2} \mathrm{SO}_{4}$ & Aerobic & 140.70 & {$[62]$} \\
\hline P. decumbens JU-A10 & Wheat bran & $\mathrm{NaNO}_{3}$, urea & Aerobic & 10.60 & {$[63]$} \\
\hline P. pinophilum & Wheat bran & $\left(\mathrm{NH}_{4}\right)_{2} \mathrm{SO}_{4}$ & Aerobic & 65.00 & {$[64]$} \\
\hline Neocallimastix sp. R1 & Wheat straw & Trypticase peptone, $\mathrm{NH}_{4} \mathrm{Cl}$ & Anaerobic & 0.19 & {$[65]$} \\
\hline N. frontalis $\mathrm{PN}-1$ & Filter paper strip & $\left(\mathrm{NH}_{4}\right)_{2} \mathrm{SO}_{4}$ & Anaerobic & 0.94 & {$[66]$} \\
\hline Neurospora crassa & Wheat straw & Yeast extract & Aerobic & 19.70 & [67] \\
\hline Trichoderma sp. A-001 & Filter paper & $\mathrm{KNO}_{3}$ & Aerobic & 167.00 & {$[68]$} \\
\hline Volvariella volvacea & Avicel & Yeast extract, $\mathrm{NH}_{4} \mathrm{NO}_{3}$ & Aerobic & 0.64 & [69] \\
\hline
\end{tabular}

CMC: carboxymethyl cellulose; OPEFB: oil palm empty-fruit-bunch fibres; CP-123: cellulose powder 123.

$\mathrm{pH}$ of 5.0 and 5.1 and an optimal temperature of $50^{\circ}$ and $55^{\circ} \mathrm{C}$, respectively $[15,35]$. However, maximum CMCase activity of bacteria at $\mathrm{pH}$ lower than 6.0 has been rarely observed, and the maximum CMCase activities of $P$. campinasensis BL11, $P$. polymyxa GS01, Paenibacillus sp. B39, and Bacillus mycoides S122C were observed at neutral or alkaline conditions [37, $38,46,47]$. In the present study, the CMCase produced by the strain ME27-1 was stable at $\mathrm{pH}$ 5.0-9.5, and almost $85 \%$ residual activity was retained. Only a few studies have reported that CMCase was stable at such a wide $\mathrm{pH}$ range; for example, Da Vinha et al. reported the 60\% CMCase activity was retained within the $\mathrm{pH}$ range of 3.0-8.0 [15].

3.5. Comparison of CMCase Production by P. terrae ME27-1 and Other Microorganisms. When measured at the optimal $\mathrm{pH}$ and temperature of CMCase, $P$. terrae ME27-1 produced CMCase activity of $2.08 \mathrm{U} / \mathrm{mL}$ under the optimized cultivation conditions, which was a 12 -fold improvement in the CMCase production. This yield of CMCase production was higher than most of the aerobic bacterial strains but less than some of aerobic bacterial strains that have been exploited previously (Table 3). However, the CMCase production by $P$. terrae ME27-1 was lower than that by several anaerobic bacterial strains, for example, Clostridium papyrosolvens CFR703, C. thermocellum YM4, C. thermocopriae JT3-3 (Table 3). Some anaerobic bacteria can degrade lignocellulosic substrates efficiently by producing multienzyme complex termed cellulosome [36]. The carbohydrate binding modules and different proteins in the cellulosome allow the whole enzyme complex to bind to the substrates, which avoids the wasteful expenditure of energy of bacteria releasing large amounts of individual enzymes and makes lots of advantages over singleenzyme system $[4,48]$.

Furthermore, the CMCase produced by $P$. terrae ME271 was lower than that by most aerobic fungal strains while it was higher than that by anaerobic fungal strains (Table 3). 
The CMCase production by most bacteria was usually lower than that by aerobic fungal strains. Genomic analysis showed that less glycosyl hydrolases existed in aerobic bacterial strains than aerobic fungal strains, which may explain why aerobic bacteria usually produce lower CMCase activity [48].

\section{Conclusion}

Ten genera of bacteria hydrolyzing cellulose were isolated from different natural reserves in the subtropical region of China, and the genus Burkholderia was found to be the most prevalent and predominant. The strain ME27-1, identified to be $P$. terrae, showed the highest CMCase activity among the 22 strains isolated, and after optimization of the cultivation conditions, the enzyme activity was significantly improved to $2.08 \mathrm{U} / \mathrm{mL}$. This bacterial species has been rarely found to produce cellulase. Thus, this study revealed the diversity of cellulose-degrading bacteria in the subtropical region of China and found that $P$. terrae ME27-1 was a good CMCase producer.

\section{Conflict of Interests}

The authors declare that there is no conflict of interests regarding the publication of this paper.

\section{Acknowledgments}

This work was supported by a Grant from the National Natural Science Foundation of China (30960013), a Grant from the Guangxi Natural Science Foundation (2012GXNSFGA060005), and the Bagui Scholar Program of Guangxi (2011A001).

\section{References}

[1] J. L. A. Brás, A. Cartmell, A. L. M. Carvalho et al., "Structural insights into a unique cellulase fold and mechanism of cellulose hydrolysis," Proceedings of the National Academy of Sciences of the United States of America, vol. 108, no. 13, pp. 5237-5242, 2011.

[2] A. V. Gusakov and A. P. Sinitsyn, "Cellulases from Penicillium species for producing fuels from biomass," Biofuels, vol. 3, no. 4, pp. 463-477, 2012.

[3] L. F. Martins, D. Kolling, M. Camassola, A. J. P. Dillon, and L. P. Ramos, "Comparison of Penicillium echinulatum and Trichoderma reesei cellulases in relation to their activity against various cellulosic substrates," Bioresource Technology, vol. 99, no. 5, pp. 1417-1424, 2008.

[4] M. Maki, K. T. Leung, and W. Qin, “The prospects of cellulaseproducing bacteria for the bioconversion of lignocellulosic biomass," International Journal of Biological Sciences, vol. 5, no. 5, pp. 500-516, 2009.

[5] R. Waeonukul, K. L. Kyu, K. Sakka, and K. Ratanakhanokchai, "Isolation and characterization of a multienzyme complex (cellulosome) of the Paenibacillus curdlanolyticus B-6 grown on Avicel under aerobic conditions," Journal of Bioscience and Bioengineering, vol. 107, no. 6, pp. 610-614, 2009.

[6] D. Deswal, Y. P. Khasa, and R. C. Kuhad, "Optimization of cellulase production by a brown rot fungus Fomitopsis sp. RCK2010 under solid state fermentation," Bioresource Technology, vol. 102, no. 10, pp. 6065-6072, 2011.

[7] F. L. Soares Jr., I. S. Melo, A. C. F. Dias, and F. D. Andreote, "Cellulolytic bacteria from soils in harsh environments," World Journal of Microbiology and Biotechnology, vol. 28, no. 5, pp. 2195-2203, 2012.

[8] K. Marjamaa, K. Toth, P. A. Bromann, G. Szakacs, and K. Kruus, "Novel Penicillium cellulases for total hydrolysis of lignocellulosics," Enzyme and Microbial Technology, vol. 52, no. 6-7, pp. 358-369, 2013.

[9] Y.-C. Lo, G. D. Saratale, W.-M. Chen, M.-D. Bai, and J.-S. Chang, "Isolation of cellulose-hydrolytic bacteria and applications of the cellulolytic enzymes for cellulosic biohydrogen production," Enzyme and Microbial Technology, vol. 44, no. 6-7, pp. 417-425, 2009.

[10] D. B. Wilson, "Microbial diversity of cellulose hydrolysis," Current Opinion in Microbiology, vol. 14, no. 3, pp. 259-263, 2011.

[11] M. M. Ekperigin, "Preliminary studies of cellulase production by Acinetobacter anitratus and Branhamella sp," African Journal of Biotechnology, vol. 6, no. 1, pp. 028-033, 2007.

[12] G. Rastogi, G. L. Muppidi, R. N. Gurram et al., "Isolation and characterization of cellulose-degrading bacteria from the deep subsurface of the Homestake gold mine, Lead, South Dakota, USA," Journal of Industrial Microbiology and Biotechnology, vol. 36, no. 4, pp. 585-598, 2009.

[13] P. Gupta, K. Samant, and A. Sahu, "Isolation of cellulosedegrading bacteria and determination of their cellulolytic potential," International Journal of Microbiology, vol. 2012, Article ID 578925, 5 pages, 2012.

[14] D. Deka, P. Bhargavi, A. Sharma, D. Goyal, M. Jawed, and A. Goyal, "Enhancement of cellulase activity from a new strain of Bacillus subtilis by medium optimization and analysis with various cellulosic substrates," Enzyme Research, vol. 2011, no. 1, Article ID 151656, 2011.

[15] F. N. M. Da Vinha, M. P. Gravina-Oliveira, M. N. Franco et al., "Cellulase production by Streptomyces viridobrunneus SCPE09 using lignocellulosic biomass as inducer substrate," Applied Biochemistry and Biotechnology, vol. 164, no. 3, pp. 256-267, 2011.

[16] P. Sheng, S. Huang, Q. Wang, A. Wang, and H. Zhang, "Isolation, screening, and optimization of the fermentation conditions of highly cellulolytic bacteria from the hindgut of Holotrichia parallela larvae (Coleoptera: Scarabaeidae)," Applied Biochemistry and Biotechnology, vol. 167, no. 2, pp. 270284, 2012.

[17] F. T. Wolf, “The production of indole acetic acid by Ustilago zeae, and its possible significance in tumor formation," Proceedings of the National Academy of Sciences of the United States of America, vol. 38, no. 2, pp. 106-111, 1952.

[18] M. Mandels and E. T. Reese, "Induction of cellulase in Trichoderma viride as influenced by carbon sources and metals," Journal of Bacteriology, vol. 73, no. 2, pp. 269-278, 1957.

[19] R. M. Teather and P. J. Wood, "Use of Congo red-polysaccharide interactions in enumeration and characterization of cellulolytic bacteria from the bovine rumen," Applied and Environmental Microbiology, vol. 43, no. 4, pp. 777-780, 1982.

[20] G. L. Miller, "Use of dinitrosalicylic acid reagent for determination of reducing sugar," Analytical Chemistry, vol. 31, no. 3, pp. 426-428, 1959.

[21] T. K. Ghose, "Measurement of cellulase activity," Pure and Applied Chemistry, vol. 59, no. 2, pp. 257-268, 1987. 
[22] R. Rawat and L. Tewari, "Purification and characterization of an acidothermophilic cellulase enzyme produced by Bacillus subtilis strain LFS3," Extremophiles, vol. 16, no. 4, pp. 637-644, 2012.

[23] Y. Feng, C.-J. Duan, H. Pang et al., "Cloning and identification of novel cellulase genes from uncultured microorganisms in rabbit cecum and characterization of the expressed cellulases," Applied Microbiology and Biotechnology, vol. 75, no. 2, pp. 319-328, 2007.

[24] K. A. Datsenko and B. L. Wanner, "One-step inactivation of chromosomal genes in Escherichia coli K-12 using PCR products," Proceedings of the National Academy of Sciences of the United States of America, vol. 97, no. 12, pp. 6640-6645, 2000.

[25] D. J. Lane, "16S/23S rRNA sequencing," in Nucleic Acid Techniques in Bacterial Systematics, E. Stackebrandt and M. Goodfellow, Eds., pp. 115-175, John Wiley \& Sons, Chichester, UK, 1991.

[26] S. Kumar, M. Nei, J. Dudley, and K. Tamura, "MEGA: a biologist-centric software for evolutionary analysis of DNA and protein sequences," Briefings in Bioinformatics, vol. 9, no. 4, pp. 299-306, 2008.

[27] J.-H. Yoon, H.-M. Oh, B.-D. Yoon, K. H. Kang, and Y.-H. Park, "Paenibacillus kribbensis sp. nov. and Paenibacillus terrae sp. nov., bioflocculants for efficient harvesting of algal cells," International Journal of Systematic and Evolutionary Microbiology, vol. 53, no. 1, pp. 295-301, 2003.

[28] S. Sadhu and T. K. Maiti, "Cellulase production by bacteria: a review," British Microbiology Research Journal, vol. 3, no. 3, pp. 235-258, 2013.

[29] M. L. Maki, M. Broere, K. T. Leung, and W. Qin, "Characterization of some efficient cellulase producing bacteria isolated from paper mill sludges and organic fertilizers," International Journal of Biochemistry and Molecular Biology, vol. 2, no. 2, pp. 146-154, 2011.

[30] Y. K. Kim, S. C. Lee, Y. Y. Cho, H. J. Oh, and Y. H. Ko, "Isolation of cellulolytic Bacillus subtilis strains from agricultural environments," ISRN Microbiology, vol. 2012, Article ID 650563, 9 pages, 2012.

[31] K. Fujii, A. Oosugi, and S. Sekiuchi, "Cellulolytic microbes in the Yanbaru, a subtropical rainforest with an endemic biota on Okinawa Island, Japan," Bioscience, Biotechnology and Biochemistry, vol. 76, no. 5, pp. 906-911, 2012.

[32] K. M. Cho, S. Y. Hong, S. M. Lee et al., "A cel44C-man26A gene of endophytic Paenibacillus polymyxa GS01 has multi-glycosyl hydrolases in two catalytic domains," Applied Microbiology and Biotechnology, vol. 73, no. 3, pp. 618-630, 2006.

[33] M. Mormeneo, F. J. Pastor, and J. Zueco, "Efficient expression of a Paenibacillus barcinonensis endoglucanase in Saccharomyces cerevisiae," Journal of Industrial Microbiology and Biotechnology, vol. 39, no. 1, pp. 115-123, 2012.

[34] I.-H. Park, J. Chang, Y.-S. Lee, S.-J. Fang, and Y.-L. Choi, “Gene cloning of endoglucanase Cel5A from cellulose-degrading Paenibacillus xylanilyticus KJ-03 and purification and characterization of the recombinant enzyme," Protein Journal, vol. 31, no. 3, pp. 238-245, 2012.

[35] S. Shinoda, S. Kanamasa, and M. Arai, "Cloning of an endoglycanase gene from Paenibacillus cookii and characterization of the recombinant enzyme," Biotechnology Letters, vol. 34, no. 2, pp. 281-286, 2012.

[36] P. Pason, K. L. Kyu, and K. Ratanakhanokchai, "Paenibacillus curdlanolyticus strain B-6 xylanolytic-cellulolytic enzyme system that degrades insoluble polysaccharides," Applied and Environmental Microbiology, vol. 72, no. 4, pp. 2483-2490, 2006.
[37] C.-H. Ko, W.-L. Chen, C.-H. Tsai, W.-N. Jane, C.-C. Liu, and J. Tu, "Paenibacillus campinasensis BL11: a wood materialutilizing bacterial strain isolated from black liquor," Bioresource Technology, vol. 98, no. 14, pp. 2727-2733, 2007.

[38] C.-M. Wang, C.-L. Shyu, S.-P. Ho, and S.-H. Chiou, "Characterization of a novel thermophilic, cellulose-degrading bacterium Paenibacillus sp. strain B39," Letters in Applied Microbiology, vol. 47, no. 1, pp. 46-53, 2008.

[39] D. Kumar, M. Ashfaque, M. Muthukumar, M. Singh, and N. Garg, "Production and characterization of carboxymethyl cellulase from Paenibacillus polymyxa using mango peel as substrate," Journal of Environmental Biology, vol. 33, no. 1, pp. 81-84, 2012.

[40] W. Gao, E.-J. Lee, S.-U. Lee, J. Li, C.-H. Chung, and J.-W. Lee, "Enhanced carboxymethylcellulase production by a newly isolated marine bacterium, Cellulophaga lytica LBH-14, using rice bran," Journal of Microbiology and Biotechnology, vol. 22, no. 10, pp. 1412-1422, 2012.

[41] B. Wen, X. Yuan, Y. Cao, Y. Liu, X. Wang, and Z. Cui, "Optimization of liquid fermentation of microbial consortium WSD5 followed by saccharification and acidification of wheat straw," Bioresource Technology, vol. 118, pp. 141-149, 2012.

[42] K. Geetha and P. Gunasekaran, "Optimization of nutrient medium containing agricultural waste for xylanase production by Bacillus pumilus B20," Biotechnology and Bioprocess Engineering, vol. 15, no. 5, pp. 882-889, 2010.

[43] H.-J. Kim, Y.-J. Lee, W. Gao, C.-H. Chung, C.-W. Son, and J.-W. Lee, "Statistical optimization of fermentation conditions and comparison of their influences on production of cellulases by a psychrophilic marine bacterium, Psychrobacter aquimaris LBH-10 using orthogonal array method," Biotechnology and Bioprocess Engineering, vol. 16, no. 3, pp. 542-548, 2011.

[44] E. Kalogeris, P. Christakopoulos, P. Katapodis et al., "Production and characterization of cellulolytic enzymes from the thermophilic fungus Thermoascus aurantiacus under solid state cultivation of agricultural wastes," Process Biochemistry, vol. 38, no. 7, pp. 1099-1104, 2003.

[45] W.-J. Lu, H.-T. Wang, S.-J. Yang, Z.-C. Wang, and Y.-F. Nie, "Isolation and characterization of mesophilic cellulose-degrading bacteria from flower stalks-vegetable waste co-composting system," Journal of General and Applied Microbiology, vol. 51, no. 6, pp. 353-360, 2006.

[46] M. C. Kye, J. H. Sun, R. K. Math et al., "Cloning of two cellulase genes from endophytic Paenibacillus polymyxa GS01 and comparison with cel44C-man26A," Journal of Basic Microbiology, vol. 48, no. 6, pp. 464-472, 2008.

[47] N. Balasubramanian, D. Toubarro, M. Teixeira, and N. Simõs, "Purification and biochemical characterization of a novel thermo-stable carboxymethyl cellulase from Azorean isolate Bacillus mycoides S122C," Applied Biochemistry and Biotechnology, vol. 168, no. 8, pp. 2191-2204, 2012.

[48] P. J. Brumm, "Bacterial genomes: what they teach us about cellulose degradation,” Biofuels, vol. 4, no. 6, pp. 669-681, 2013.

[49] T. Shankar and L. Isaiarasu, "Cellulase production by Bacillus pumilus EWBCM1 under varying cultural conditions," MiddleEast Journal of Scientific Research, vol. 8, no. 1, pp. 40-45, 2011.

[50] O. S. Kotchoni, O. O. Shonukan, and W. E. Gachomo, "Bacillus pumilus BpCRI 6, a promising candidate for cellulase production under conditions of catabolite repression," African Journal of Biotechnology, vol. 2, no. 6, pp. 140-146, 2003.

[51] A. L. Grigorevski De Lima, R. Pires Do Nascimento, E. P. Da Silva Bon, and R. R. R. Coelho, "Streptomyces drozdowiczii 
cellulase production using agro-industrial by-products and its potential use in the detergent and textile industries," Enzyme and Microbial Technology, vol. 37, no. 2, pp. 272-277, 2005.

[52] Z. Jaradat, A. Dawagreh, Q. Ababneh, and I. Saadoun, "Influence of culture conditions on cellulase production by Streptomyces sp. (strain J2)," Jordan Journal of Biological Science, vol. 1, no. 4, pp. 141-146, 2008.

[53] E. P. Macedo, C. L. O. Cerqueira, D. A. J. Souza, A. S. R. Bispo, R. R. R. Coelho, and R. P. Nascimento, "Production of cellulosedegrading enzyme on sisal and other agro-industrial residues using a new Brazilian actinobacteria strain Streptomyces sp. SLBA-08," Brazilian Journal of Chemical Engineering, vol. 30, no. 4, pp. 729-735, 2013.

[54] F.-J. Chu, C.-W. Lin, Y.-P. I, C.-H. Wu, and D.-H. Chen, "Hydrolysis of bamboo cellulose and cellulase characteristics by Streptomyces griseoaurantiacus ZQBC691," Journal of the Taiwan Institute of Chemical Engineers, vol. 43, no. 2, pp. 220-225, 2012.

[55] Y. Mori, "Comparison of the cellulolytic systems of Clostridium thermocellum YM4 and JW20," Biotechnology Letters, vol. 14, no. 2, pp. 131-136, 1992.

[56] F. Jin and K. Toda, "Nutrient effects on cellulase production by the new species, Clostridium thermocopriae," Applied Microbiology and Biotechnology, vol. 31, no. 5-6, pp. 597-600, 1989.

[57] D. S. Rani, S. Thirumale, and K. Nand, "Production of cellulase by Clostridium papyrosolvens CFR-703," World Journal of Microbiology and Biotechnology, vol. 20, no. 6, pp. 629-632, 2004.

[58] R. Assareh, H. Shahbani Zahiri, K. Akbari Noghabi, S. Aminzadeh, and G. Bakhshi khaniki, "Characterization of the newly isolated Geobacillus sp. T1, the efficient cellulase-producer on untreated barley and wheat straws," Bioresource Technology, vol. 120, pp. 99-105, 2012.

[59] M. S. Umikalsom, A. B. Ariff, Z. H. Shamsuddin, C. C. Tong, M. A. Hassan, and M. I. A. Karim, "Production of cellulase by a wild strain of Chaetomium globosum using delignified oil palm empty-fruit-bunch fibre as substrate," Applied Microbiology and Biotechnology, vol. 47, no. 5, pp. 590-595, 1997.

[60] R. Lucas, A. Robles, M. T. García, G. A. De Cienfuegos, and A. Gálvez, "Production, purification, and properties of an endoglucanase produced by the hyphomycete Chalara (syn. Thielaviopsis) paradoxa CH32," Journal of Agricultural and Food Chemistry, vol. 49, no. 1, pp. 79-85, 2001.

[61] L. M. F. Gottschalk, R. A. Oliveira, and E. P. D. S. Bon, "Cellulases, xylanases, $\beta$-glucosidase and ferulic acid esterase produced by Trichoderma and Aspergillus act synergistically in the hydrolysis of sugarcane bagasse," Biochemical Engineering Journal, vol. 51, no. 1-2, pp. 72-78, 2010.

[62] M. G. Adsul, J. E. Ghule, R. Singh et al., "Polysaccharides from bagasse: applications in cellulase and xylanase production," Carbohydrate Polymers, vol. 57, no. 1, pp. 67-72, 2004.

[63] X. Sun, Z. Liu, K. Zheng, X. Song, and Y. Qu, "The composition of basal and induced cellulase systems in Penicillium decumbens under induction or repression conditions," Enzyme and Microbial Technology, vol. 42, no. 7, pp. 560-567, 2008.

[64] R. Singh, A. J. Varma, R. Seeta Laxman, and M. Rao, "Hydrolysis of cellulose derived from steam exploded bagasse by Penicillium cellulases: comparison with commercial cellulase," Bioresource Technology, vol. 100, no. 24, pp. 6679-6681, 2009.

[65] S. E. Lowe, M. K. Theodorou, and A. P. J. Trinci, "Cellulases and xylanase of an anaerobic rumen fungus grown on wheat straw, wheat straw holocellulose, cellulose, and xylan," Applied and Environmental Microbiology, vol. 53, no. 6, pp. 1216-1223, 1987.
[66] D. O. Mountfort and R. A. Asher, "Production and regulation of cellulase by two strains of the rumen anaerobic fungus Neocallimastix frontalis," Applied and Environmental Microbiology, vol. 49, no. 5, pp. 1314-1322, 1985.

[67] M. D. Romero, J. Aguado, L. González, and M. Ladero, "Cellulase production by Neurospora crassa on wheat straw," Enzyme and Microbial Technology, vol. 25, no. 3-5, pp. 244-250, 1999.

[68] B. A. Gashe, "Cellulase production and activity by Trichoderma sp. A-001," Journal of Applied Bacteriology, vol. 73, no. 1, pp. 7982, 1992.

[69] Y. J. Cai, S. J. Chapman, J. A. Buswell, and S.-T. Chang, "Production and distribution of endoglucanase, cellobiohydrolase, and $\beta$-glucosidase components of the cellulolytic system of Volvariella volvacea, the edible straw mushroom," Applied and Environmental Microbiology, vol. 65, no. 2, pp. 553-559, 1999. 

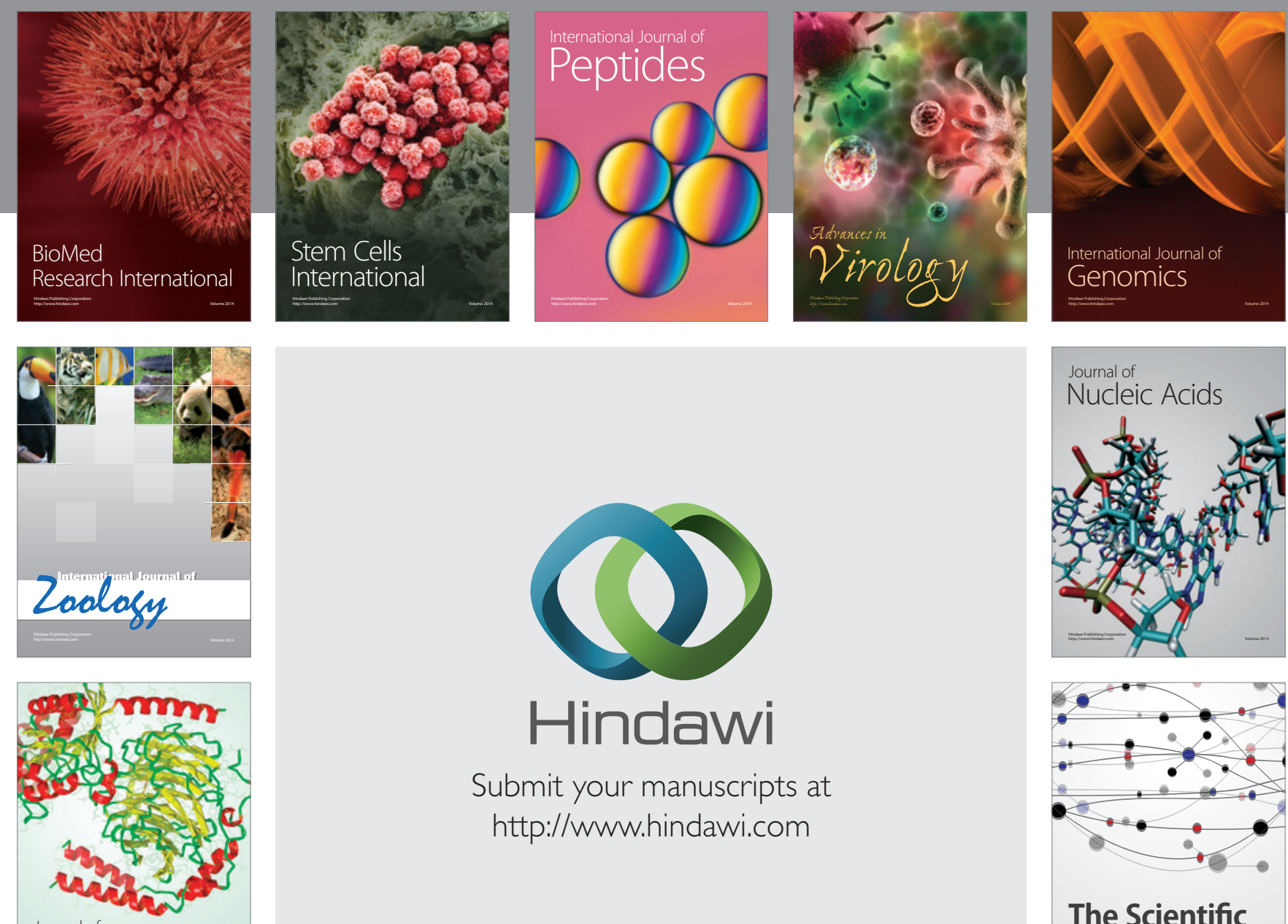

Submit your manuscripts at

http://www.hindawi.com

Journal of
Signal Transduction
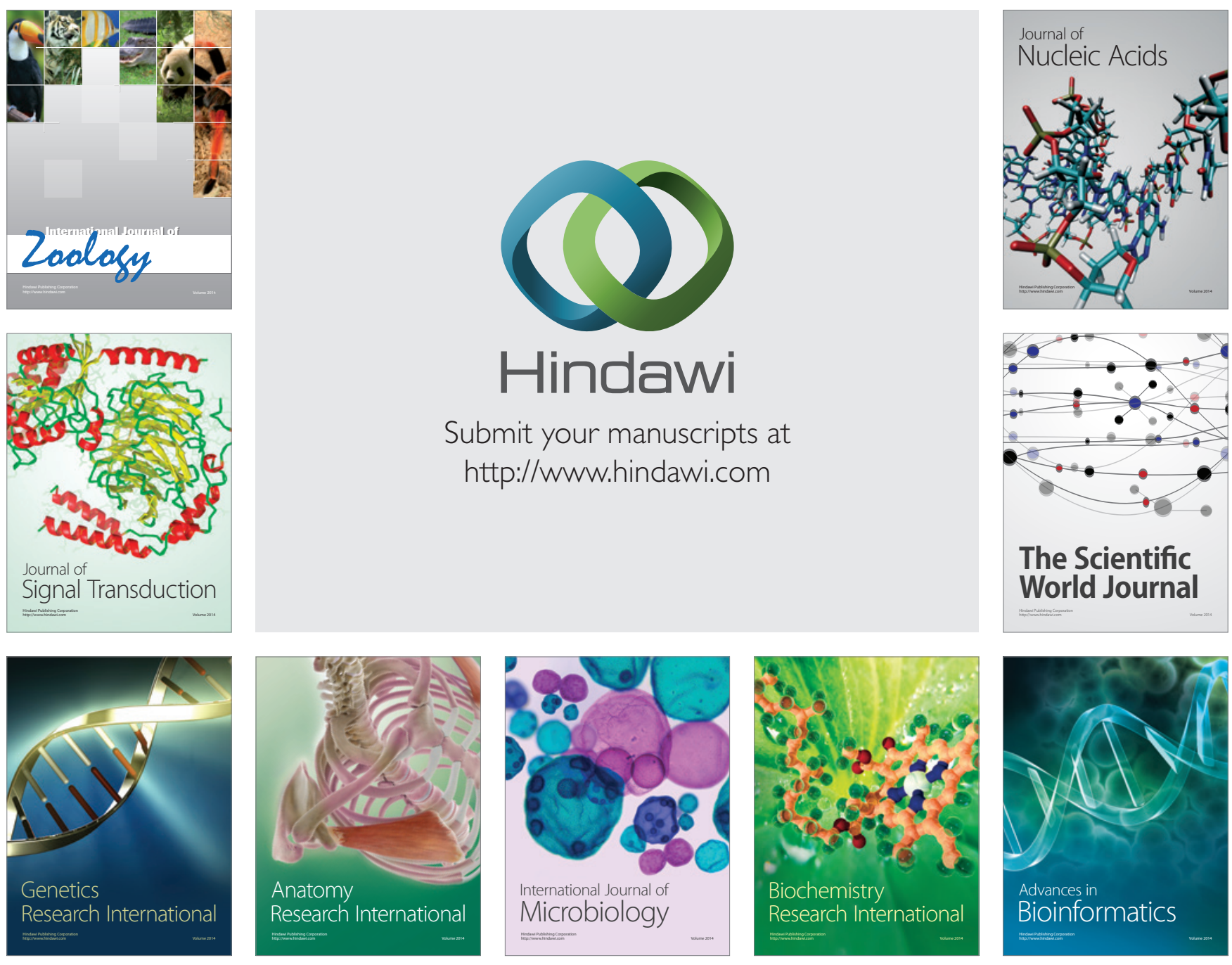

The Scientific World Journal
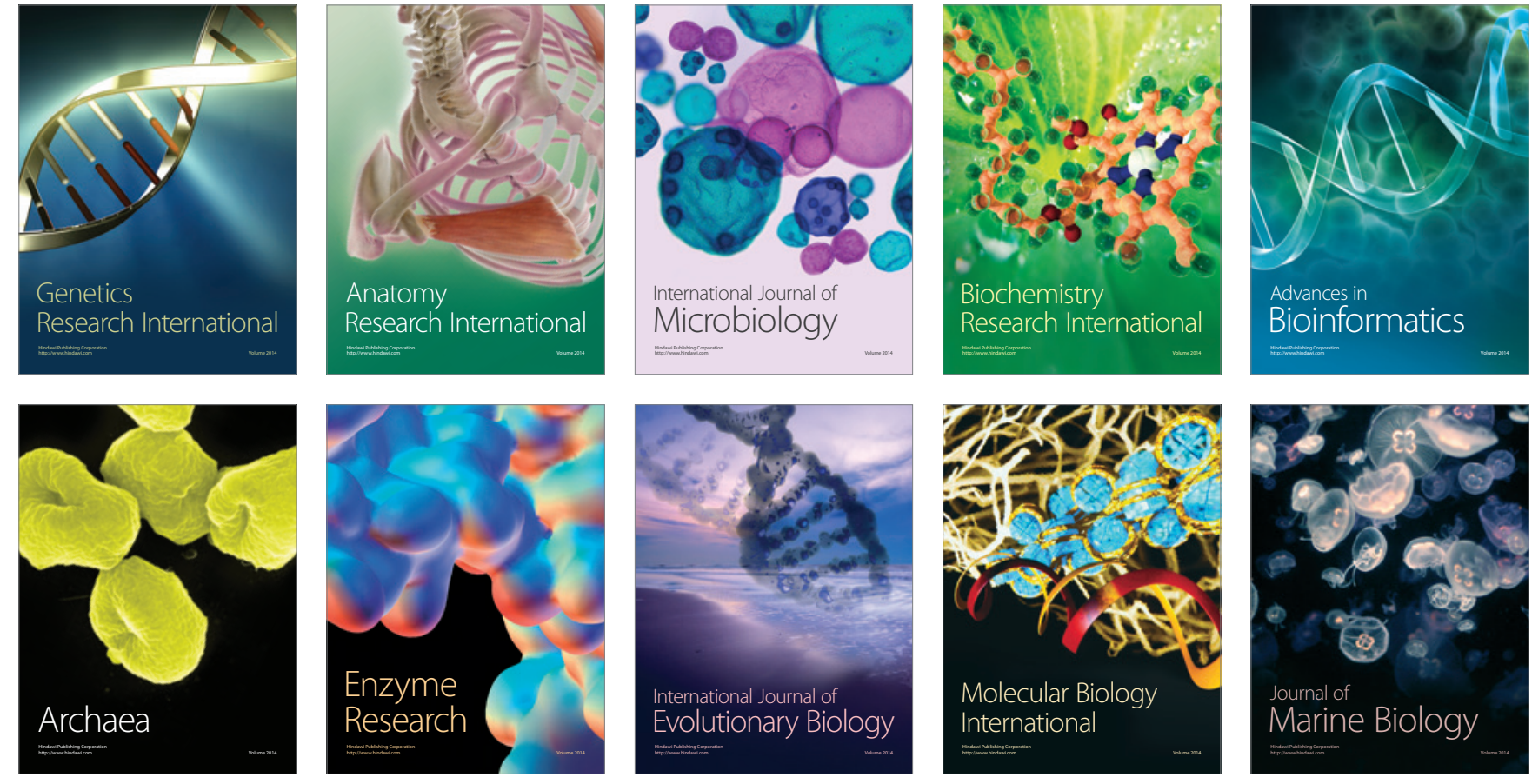